УДК 711.4.01

\title{
ПРОБЛЕМЫ РОССИЙСКОГО ГРАДОСТРОИТЕЛЬСТВА ХХ-ХХІ ВЕКОВ В КОНТЕКСТЕ КУЛЬТУРНО-ЦИВИЛИЗАЦИОННОГО РАСПАДА ПОСТИНДУСТРИАЛЬНОГО ОБЩЕСТВА
}

\author{
Часть I. Развитие ситуации до 60-х годов XX века
}

\author{
Ашихмин Александр Викторович \\ доцент \\ Шестопалова Натальия Владимировна \\ доцент \\ кафедра архитектуры и градостроительства \\ ФГБОУ ВО ИрНИТУ
}

Аннотация: Исследование посвящено социокультурным, архитектурнохудожественным и композиционно-пространственным проблемам современного российского градостроительства. Публикуемая в монографии первая часть работы рассматривает примеры и истоки очевидной ущербности социально-экологических, эстетических и композиционно-пространственных разделов создания и реализации действующей нормативной и продуцируемой архитектурной и градостроительной документации в нескольких ракурсах: общекультурная парадигма ситуации; национальные особенности и историкополитические предпосылки; региональные проблемы и перспективы. Приводятся и анализируются иллюстрации как успешных градостроительных решений и концепций, так и негативные архитектурные примеры из практики Москвы, Новосибирска, Иркутска. Подробно рассматриваются факторы общекультурной деградации современной мировой цивилизации, в контексте которой в течении 50 лет происходит и деградация русского градостроительного искусства. За канву исследования при этом приняты тезисы О. Шпенглера из книги «Закат Европы» (1918 г.), впервые в истории противопоставившего понятия «культура» и «цивилизация».

Ключевые слова: Культура, цивилизация, искусство, творчество, градостроительство, силуэт города, архитектурный ансамбль, композиция, произведение, утрата преемственности развития. 


\title{
PROBLEMS OF RUSSIAN URBAN PLANNING OF THE XX-XXI CENTURIES IN THE CONTEXT OF CULTURAL AND CIVILIZATIONAL DEVELOPMENT THE COLLAPSE OF POSTINDUSTRIAL SOCIETY
}

\section{Part I. The development of the situation up to the 60s of the XX century}

\author{
Ashikhmin Alexander Viktorovich \\ Shestopalova Natalia Vladimirovna
}

\begin{abstract}
The research is devoted to the socio-cultural, architectural-artistic, and compositional-spatial problems of modern Russian urban planning. The first part of the work, published in the monograph, examines the examples and sources of the obvious shortcomings of the socio-ecological, aesthetic and compositionalspatial sections of the creation and implementation of the existing normative and produced architectural and urban planning documentation in several perspectives: the general cultural paradigm of the situation; national features and historical and political prerequisites; regional problems and prospects. Illustrations of successful urban planning solutions and concepts, as well as negative architectural examples from the practice of Moscow, Novosibirsk, and Irkutsk are presented and analyzed. The article considers in detail the factors of the general cultural degradation of the modern world civilization, in the context of which the degradation of the Russian urban planning art has been taking place for 60 years. For the outline of the study, the theses of O.Spengler from the book "The Decline of the Western World»" (1918), which for the first time in history contrasted the concepts of "culture" and "civilization", are accepted.
\end{abstract}

Key words: Culture, civilization, art, creativity, art of the building cities, city silhouette, architectural ensemble, composition, successful work, loss of continuity of development.

\section{Глава 1. Культурологическая преамбула}

На переломе XIX и XX веков, вплоть до середины последнего - годы, отмеченные тектоническими социально-политическими потрясениями национальных революций и двумя мировыми войнами, - в коллективном разуме писателей, художников и философов-провидцев сформировалась и была сформулирована принципиальная картина циклической смены 
исторически сложившихся культурно-цивилизационных эпох: замкнутых, обособленных этапов развития человечества, в зарождении каждого из которых приоритетную роль играли сакральные идеологические (религиозные) ценности и отвечающие им культурно-эстетические образы, дошедшие до нас в материальных и былинных памятниках искусств, а в финальной стадии которых происходил какой-либо технократический перекос, совпадающий с эгоистической монетарно-материальной узурпацией власти, моральной деградацией и распадом общества. Что и приводило к кардинальной смене общественной формации и новому витку развития человечества, повторяющему, в свою очередь, не продолжительность, суть и содержание предыдущих этапов, но всю их последовательность: от зарождения, роста и прогресса - до печального конечного результата (по аналогии с жизненным циклом любого живого организма).

В русской художественной литературе этого периода, в книгах Н.В. Гоголя, А.П. Чехова; И.А. Бунина, и особенно ярко - в произведениях Ф.М. Достоевского «Бесы», поэзии А.А. Блока и В.В. Маяковского и, позднее, в романе 20-х годов А.А. Богданова «Красная звезда» (который считался фантастическим, так как в нем предсказывалась гибель цивилизации из-за истощения природных ресурсов планеты и деградации культуры) - наиболее остро прочувствовано непримиримое несоответствие одухотворенной культуры (в широком смысле этого понятия) и самой сущности властных атрибутов и их обладателей, генетически обреченных на стимуляцию непрерывного технико-технологического прогресса с параллельным сокращением любых «побочных» затрат на развитие эффективного здравоохранения, образования и искусств - в ущерб гуманистическому общественноличностному совершенствованию и самому существованию человекагражданина, становящегося лишним в пищевой цепочке псевдо-элит.

Философы разных стран, в том числе великие русские мыслителидухоборцы: Н.Я. Данилевский, К.Н. Леонтьев, В.С. Соловьев, И.В. Киреевский, Н.А. Бердяев и другие, в своих трудах также ставили данную проблему на ведущее место. Поэтически эту деструкцию этапа/общественной формации в ее финальной стадии, то есть потерю духовной составляющей бытия и его дальнейшую бессмысленность, предвосхитил Н.А. Некрасов в стихотворении «Размышления у парадного подъезда»: «...Все, что мог, ты уже совершил - Создал песню, подобную стону. И духовно навеки почил». 
Но особенно развернуто представлена и системно обоснована взаимосвязь уровня культуры, искусств и духовных идеалов общества со становлением, развитием и разрушением структуры эпохальных формаций в гениальном философском трактате немецкого мыслителя О. Шпенглера «Закат Европы»: «Der Untergang des Abendlandes» (имеющем еще версию перевода как «Падение Запада»), опубликованном в двух томах в Мюнхене в 1918-1922 гг. и многократно переизданном в разных странах и в разные годы.

Если Карл Маркс и Фридрих Энгельс в своих великих трудах ставили во главу формирования и смены общественной формации прежде всего материально-имущественную составляющую и системные факторы еe перераспределения, и в этом направлении их исследования фундаментальны и до сих пор находятся на непревзойденном уровне, то Огюст Шпенглер впервые вывел прямую зависимость оценки стадии перспективности или спада - тупикового завершения общественного строя/эпохи, от качественного уровня состояния культуры, искусства, образования и духовного развития отдельных граждан и всего сообщества людей и народов, формально объединенных на данном этапе и территориях в определенные организационно-государственные структуры и границы, а по сути, в современных условиях, неразрывно связанных в единую матрицусубкультуру.

К числу «великих культур», вполне реализовавших свои потенции, Шпенглер относит китайскую, вавилонскую, египетскую, индийскую, античную, византийско-арабскую, западную, культуру майя, а также «пробуждающуюся русско-сибирскую». Уникальность каждой культуры, по Шпенглеру, обеспечивается своеобразием её «души»: в основе античной культуры лежит «аполлоновская» душа, арабской - «магическая», западной «фаустовская» и т. д.: «В гнездах определенных ландшафтов_(Шиенглер любит слово ландшафт, и все время говорит о духовных, душевных и музыкальных ландшафтах) - на берегу Средиземного моря, в долине Нила, в просторах Азии, на средне-европейских равнинах рождаются души великих культур. Родившись, каждая из них восходит к своей весне и своему лету, спускается к своей осени и умирает своею зимой. Этому роковому кругу жизни внешней соответствует столь же роковой круг внутренней жизни духа. Душа каждой эпохи неизбежно совершает свой круг от жизни к смерти, от культуры к цивилизации» [1]. 


\section{ИННОВАЦИОННОЕ РАЗВИТИЕ НАУКИ: ФУНДАМЕНТАЛЬНЫЕ И ПРИКЛАДНЫЕ ПРОБЛЕМЫ}

И, бесспорно, философ отстоял свою правоту обширным, многоуровневым и аргументированным исследованием, посвященным доказательству теоремы несовпадения понятий «культура» и «цивилизация», которое точно и полно прокомментировано во введении А.П. Дубнова к современному российскому изданию книги О. Шпенглера в 2016г:

«Различение культуры и цивилизации Н. Бердяев отнес к самым большим достоинствам книги «Закат Европы», соглашаясь, что философия $u$ искусство существуют лишь в культуре, а в циивилизации они невозможны и не нужны. Культура, - развивал он мысль Шпенглера - органична, цивилизация - механистична, культура опирается на неравенство людей, на их качество как творческих личностей. Цивилизация проникнута стремлением к равенству, апеллирует к количеству (отметим, что на этом было основано и примитивное понимание принципов социализма идеологами КПСС в Советском Союзе, приведшее страну к краху - прим. авторов). Культура аристократична, цивилизация - демократична.

Поэтому многие русские писатели и мыслители неприязненно относились не к самому Западу, а к западной цивилизации. Все русские религиозные мыслители также видели разницу между культурой и цивилизацией. И все они испытывали ужас от сознания близкой гибели культуры и скорого торжества цивилизации, которую отождествляли с мещанством. Всем русским «культурным» людям и капитализм, и социализм представлялись одинаково зараженными духом пошлого зла» [2].

Чтобы завершить представление о «методе Шпенглера», нельзя не привести полностью еще одну цитату из предисловия к первому изданию в России книги «Закат Европы» 1922 года, написанного Ф.А. Степуном: «Цивилизация - это умирание созидающих энергий в душе; проблематизм мирочувствования; замена вопросов религиозного и метафизического характера вопросами этики и жизненной практики. В искусстве - распад монументальных форм, быстрая смена чужих входящих в моду стилей, роскошь, привычка и спорт. В политике - превращение народных организмов в практически заинтересованные массы, господство механизма и космополитизма, победа мировых городов над деревенскими далями, власть четвертого сословия. Цивилизация представляет собой, таким образом, по Шпенглеру неизбежную форму смерти каждой изжившей себя культуры. Смерть мифа в безверии, живого творчества в мертвой работе, космического 


\section{ИННОВАЦИОННОЕ РАЗВИТИЕ НАУКИ: ФУНДАМЕНТАЛЬНЫЕ И ПРИКЛАДНЫЕ ПРОБЛЕМЫ}

разума в практическом рассудке, нации в интернационале, организма в механизме» [1].

И вот - наши дни, так называемый период постиндустриализма, век высоких, в том числе цифровых, технологий (по сути - нового международного языка коммуникации людей, этакого современного «эсперанто»). Вряд ли можно уже оспорить тот факт, что в последние десятилетия XX и первые двадцать лет XXI веков, то есть уже порядка лет пятидесяти, как в мировом масштабе, так и непосредственно в России, в области музыкальной, литературной, театральной, художественной (в том числе архитектурной) культуры наблюдается серьезный застой и, более того, деградация, вызванная, прежде всего, утратой общечеловеческих и национальных духовнонравственных ориентиров, опошливанием морально-этических ценностей и идеологическим нигилизмом, ставшим в последние годы основной межконфессиональной религией. Не последнюю роль в сглаживании и усреднении заниженных требований к развитию человека в современном мире играют цифровые технологии, роботизация, компьютеризация и внедрение в производство и жизнь иных автоматизи-рованных процессов, переориентирующих целевые установки людей - от стремления к всестороннему саморазвитию личности, новым открытиям, многогранному образованию и наивысшим личным духовно-нравственным постижениям, - на почти гарантированное потребление готового продукта среднего качества во всех областях жизни: как на физическом и бытовом уровне, так и в образовании и культурной сфере, где господствуют эрзац-заменители, комиксы, болванки из чужих или чуждых рук, и близко не приближающиеся к величайшим произведениям искусства XVI - средины XX веков.

Именно это состояние общества, в котором уже давно нет понастоящему великих произведений и авторов: композиторов, писателей, поэтов, художников, архитекторов - творцов, именами которых назывались концептуальные стили искусств и целые эпохи, и которые становились символами своего времени, и называл О. Шпенглер «цивилизацией», и именно это состояние упадка культуры является, по его предвидению и по нашему мироощущению, наиболее яркой приметой скорого краха очередной общественной формации.

Если рассматривать текущую ситуацию по российскому образцу, становится очевидной суть проблемы: нет новаторских идей или шедевров, 
повсюду вторичность и посредственность, безальтернативно культивируемая «сверху» и поддерживаемая «снизу». Стоит лишь задаться вопросами: где композиторы уровня Чайковского, Глинки, Стравинского, Шостаковича, или хотя бы Хачатуряна, Дунаевского и Пахмутовой?; где писатели - такие, как Толстой, Достоевский, Чехов, Булгаков, Горький, Симонов, Шолохов; поэты как Пушкин и Лермонтов, Некрасов, Блок, Цветаева и Ахматова, Маяковский и Пастернак, или наши шестидесятники - Вознесенский, Рождественский, Ахмадуллина, Евтушенко?; художники - Перов, Репин, Левитан, Врубель, Кандинский, Пластов и другие? Где великие артисты и драматурги, судьбоносные спектакли? Где настоящие архитекторы: от Стасова и Коробова, Щусева, братьев Весниных и Голосова до Алабяна, Жолтовского и Посохина, а также - Бурова, Бархина, Баранова, Лежавы, Гутнова и ряда других подлинных градостроителей?! Нет идеологий и идеологов, теорий и теоретиков. Есть лишь небольшой список талантливых исполнителей всех направлений искусства, не находящих полноценной реализации в обескультуренной общественной среде.

И этот перечень некем продолжить не потому, что при жизни мы не ценим своих современников или, по Блоку, «большое видится на расстоянии», - просто нет этого Большого, за редчайшим исключением, и то не находящим себе применения: измельчали «творцы», иссяк родник идей и концепций ввиду запрограммированного злым гением цивилизации глобального общественно-культурного запроса шаблонов и лэйблов ширпотреба, транслируемого и насаждаемого по интернету и на государственном информационном уровне, через искореженные учебники истории и обществознания в школах и вузах, через замену личного познания мира в библиотеках и экспедициях на легкодоступную, пусть чужую и переваренную, компьютерную жвачку - вероятно, для создания единого класса (или кластера?) обслуживающего персонала.

Эти раздумья, мучающие каждого неравнодушного и способного самостоятельно мыслить гражданина России, к сожалению, подтверждают вывод, содержавщийся в редакционном введении в русское издание книги О. Шпенглера «Закат Европы»: «Так что же, и наша «великая русская», славянская, культура «прекратила течение свое»? Похоже, что так. Ведь, согласно методу Шпенглера, уже сама горечь по поводу упадка своей культуры есть первейший признак ее декаданса» [2]. 


\section{Глава 2. Советская архитектура и политико-эстетическая}

\section{гильотина 1955 года}

К сожалению, канули в Лету времена, когда творческие поиски и теоретические концепции советских архитекторов (в частности конструктивизм 20-х годов прошлого века и некоторые уникальные градостроительные идеи: «Линейный город», «НЭР», «Прерывная кинетическая система расселения», другие научные исследования в области архитектурной теории и композиции) становились объектами обсуждения, восхищения и, в ряде случаев, копирования для западных коллег, а обусловленные общенародной государственной собственностью на землю и ресурсы возможности комплексного градостроительного планирования и единовременного централизованного проектирования и застройки целых городов и районов - предметом нескрываемой зависти проектировщиковурбанистов и городских администраторов всех без исключения капиталистических государств (что, кстати, косвенно свидетельствует о сильной недореализованности потенциала социалистического строя).

Если в российской архитектуре, за редким исключением, и в ряде архитектурных произведений на территориях большинства бывших советских республик прослеживается массовая тенденция более или менее успешного копирования трендовых архитектурных тенденций и приемов, продуцируемых и продюссируемых в различных интерпретациях несколькими ведущими архитектурными школами Запада, то ситуация в постсоциалистическом градостроительстве России, на наш взгляд, складывается вообще кризисно.

И дело не только и не столько в личных профессиональных качествах или возможностях конкретных специалистов-градостроителей, особенно подготовленных в советских архитектурных школах и имеющих научнопрактический опыт прежних лет: с этим к концу прошлого столетия было как раз все более чем нормально, да и сейчас еще есть возможности и люди, способные, преемственно опираясь на опыт советской и международной архитектурно-научной школы, поднять градостроительную теорию и практику на высокий уровень, нормативно формализовать организационные процессы и создать достойный продукт: современную комплексную комфортную и эстетически высококачественную архитектурно-ландшафтную среду; в том числе урбанизированную, при наличии должных условий и 
обоснованной необходимости; в том числе гармоничную, при преобразовании/реконструкции исторически сложившейся застройки; и в том числе гуманистичную, т.е. сомасштабную человеку и природной среде, художественно-выразительную, ориентированную прежде всего на комплекс потребностей постоянного населения и гостеприимную по отношению к новым или временным членам сообществ поселений.

На самом деле, скорость «контрреволюционного» слома социалистической общественной формации и замены ее в России суррогатным государственно-олигархическим капитализмом застали врасплох культурнообразовательную элиту интеллигенции, потерявшую к 90-м годам силу и свежесть мысли и безропотно «слившую» лидирующие позиции в обществе в силу рефлекторно-объективной оценки собственной творческой несостоятельности и страха, впитавшегося в умы и души нескольких поколений еще за годы сталинских репрессий.

Безусловно, в 90-х и 2000-х не смогли удержать позиции абсолютно все творческие союзы, лишенные финансирования, пропаганды и господдержки, в их числе и архитекторы-градостроители, даже не привлеченные к разработке действующего Градостроительного кодекса РФ. Это произошло не одномоментно. Престиж архитектора и роль архитектуры, как вида искусства, целенаправленно занижались начиная с Хрущевского переворота во всех сферах общественно-культурной и административно-производственной деятельности, в том числе в области градостроительства - после печально знаменитого декабрьского 1954 года Всесоюзного совещания строителей, ликвидации в 1955 году Академии архитектуры и, наконец, Постановления ЦК КПСС от 04.11.1955г. «Об устранении излишеств в проектировании и строительстве»: «...Быв. Академия Архитектуры СССР и ее научноисследовательские институты не дали своевременно критической оценки проявлениям формализма и другим крупным недостаткам в архитектуре, оторвались от жизни. Во многих своих работах эта Академия была носителем одностороннего, эстетского понимания архитектуры, преувеличивала и искажала роль классического наследия, прививала некритическое отношение к нему. Государственный комитет Совета Министров СССР по делам строительства не проводил должной работы по ликвидации излишеств в проектировании и строительстве. Архитектурная секция по Сталинским премиям в области литературы и искусства представляла предложения о 
присуждении Сталинских премий за работы, содержащие крупные излишества и неправильные планировочные решения...». Ну, и так далее, с предписаниями об увольнении ряда ведущих архитекторов проектных институтов, смене руководства Союза архитекторов, изменении программы подготовки архитектурных кадров от индивидуального в сторону типового проектирования (по существу, убивалось творческое мышление и сама его необходимость), и даже с отменой нескольких Сталинских премий (последнего постановления, утвержденного И.В. Сталиным еще буквально 2 года назад). Особенно задевает пренебрежительное сокращение «Быв. Академия...», не имеющее аналогов в официальных печатных изданиях [7].

Генеральный секретарь ЦК КПСС Н.С. Хрущев инстинктивно чувствовал значимость архитектуры и градостроительства в общественном восприятии и сознании, и сохранение понятий «сталинская архитектура», «сталинская премия» было для него совершенно неприемлемым: он стремился отодвинуть профессионалов, создать собственный стиль, «типаж», выражаясь театрально-киношным слэнгом, оставить след в архитектурном облике страны, и ему это в полной мере удалось (рис.1,2).

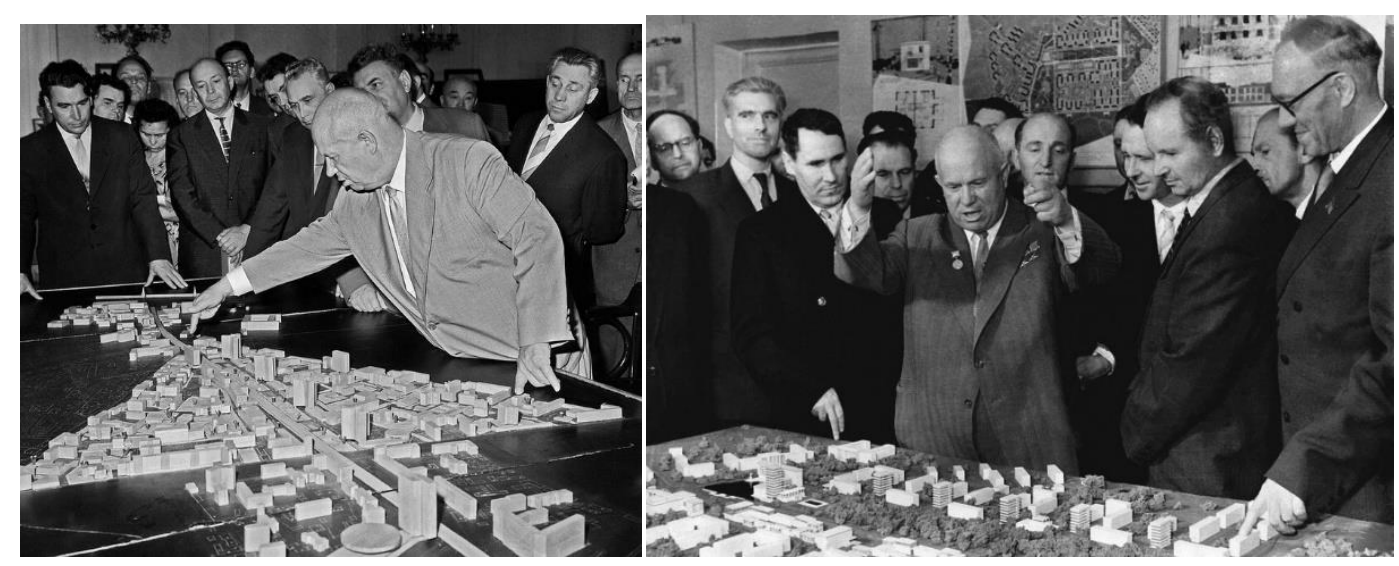

Рис. 1, 2. Н.С. Хрущев «руководит» расстановкой «коробочек» Калининского проспекта в Москве и обсуждением застройки Академгородка в Новосибирске (архивы Яндекса)

Авторитарный и харизматичный, но недостаточно образованный и культурный партийный лидер страны («немного походил в церковноприходскую школу», учился (ли?) на рабфаке и в Промакадемии для партхозактива» [4]), при действительно назревшей необходимости реформ в строительстве для массового обеспечения населения жильем, хотел, в 
значительной мере из-за личных политических амбиций, поменять вектор развития советской архитектуры - путем сплошной индустриализации строительства и типизации проектирования, стремясь, по аналогии с коллективизацией села и индустриализацией производства $20-\mathrm{x}-40$-х годов мгновенно изменить ситуацию.

Это было сделано топорно, не просчитывая отдаленных последствий и не сознавая многоаспектности и взаимосвязанности направлений архитектурно-градостроительной деятельности, ее исторических культурногенетических корней, необходимости соблюдения принципа архитектурной (формотворческой), композиционной преемственности - по крайней мере, в условиях реконструкции исторически сложившейся застройки.

Уже тогда архитектурное образование, его исторические разделы, теоретико-композиционные и архитектурно-художественные курсы были значительно урезаны в пользу общетехнических, экономических и общественно-политических дисциплин. В том же постановлении «Об устранении излишеств...» было прямо указано: «В Московском архитектурном институте и в некоторых других учебных заведениях студентам прививается односторонний, эстетский подход к проектированию жилых, промышленных и общественных зданий. Значительная часть профессорско-преподавательского состава культивирует некритическое отношение студентов к использованию архитектурных приемов и форм прошлого, ориентирует студентов не разработку только художественных задач. В подготовке молодых архитекторов имеет место игнорирование насущных задач массового строительства и типового проектирования, а также вопросов экономики, современной строительной техники и рациональной эксплуатации зданий и сооружений...» [7].

Значение роли архитектора, как главного строителя, было нивелировано и подчинено интересам строительных государственных управлений и трестов; главный архитектор города фактически из стратега превратился в статиста, а вместе с этим пострадал архитектурно-художественный облик советских городов. Многие из них, особенно моногорода 50-х-70-х годов при промышленных объектах, а также микрорайоны массовой застройки этого времени в крупных административных центрах, теперь не имеют своего индивидуального лица и, с точки зрения безопасности, комфорта и эстетики городской среды, неблагоприятны для проживания. Форма управления 
государством и общественный строй в стране сейчас коренным образом поменялись, а архитектура, как бы по инерции, так и осталась в роли служанки при строительной отрасли. Также тогда пострадала и стратегическая экономическая эффективность государственных капиталовложений, декларируемая, наряду с объемами жилищного строительства, как основная цель реформ: крупнопанельные жилые пятиэтажки - «хрущевки», «серии», возводились в кратчайшие сроки, но практически из аналогичных конструкций в самых разных природно-климатических районах огромной страны. Теперь повсеместно, особенно в Сибири, на Севере и на Дальнем Востоке, то есть в зонах экстремального контраста температурновлажностного режима эксплуатации, их наружные стеновые панели начали выходить из строя и активно саморазрушаться. Это еще без учета аспектов чрезвычайно низкой энергоэффективности неутепленных бетонных стен и перекрытий крупнопанельных домов; неконтролируемой коррозии металла арматуры в скрытых соединительных узлах конструкций (опасность крушения); некомфортности микроклимата и тесноты жилых помещений (которые из-за жестких конструктивных схем зданий невозможно перепланировать). Ущербным стал архитектурно-художественный облик жилых районов и городской застройки этого периода в целом (рис.4).

Перефразируя афоризм Л.И. Брежнева «Экономика должна быть экономной», в данном случае следовало бы добавить «и расчетливой», то есть не однодневной, а с учетом выбора вариантов среднесрочной и длительной эксплуатационной перспективы строительства. Из классической триады Витрувия, утверждавшего, что архитектура есть «польза, прочность и красота», к сегодняшнему массиву жилой застройки хрущевского периода, на сегодня составляющему около $1 / 2$ всего жилого фонда страны (данные РБК на 2017г. [16]), можно отнести, и то с обоснованными выше серьезными сомнениями, лишь одну составляющую - «польза», добавив еще характеристику «проблема».

Таким образом, жизнь опровергла основные доводы постановления «Об устранении излишеств...», направив их острие против догматического навязывания не понятой авторами и искаженной исполнителями социальной сути непрерывного, в историческом культурном контексте, архитектурностроительного процесса: жилые, общественные и промышленные здания классической архитектуры, созданные из традиционных материалов в XVII- 
середине XX веков, или предвосхитившие будущее, построенные с применением передовых, новаторских композитных конструктивных схем, блочно-модульных стеновых элементов и уникальных строительномонтажных технологий (высотные здания Москвы и жилые крупоноблочные здания 50-х годов XX века), оказались универсальной, надежной и долговечной функционально-эстетической оболочкой пространств жизнедеятельности человека. А хрущевский формально-коллективизаторский «наскок» - временным и опасным, чрезвычайно затратным с сегодняшних позиций явлением.

Справедливости ради следует отметить, что так называемая «рациональная архитектура» стала в этот период интернациональной темой: упрощение конструкций и форм, индустриализация и стремление к модульности, повторяемости крупноблочных архитектурных элементов и удешевлению строительства, не обошли стороной и развитые западные страны (рис.3) - что, в принципе, могло бы признаваться логичным и справедливым, не наноси это течение такого ущерба эстетическим и композиционным вопросам градостроительства (рис.4), принципам преемственности формирования архитектурно-художественного облика городов, особенно в исторически сложившейся городской среде.

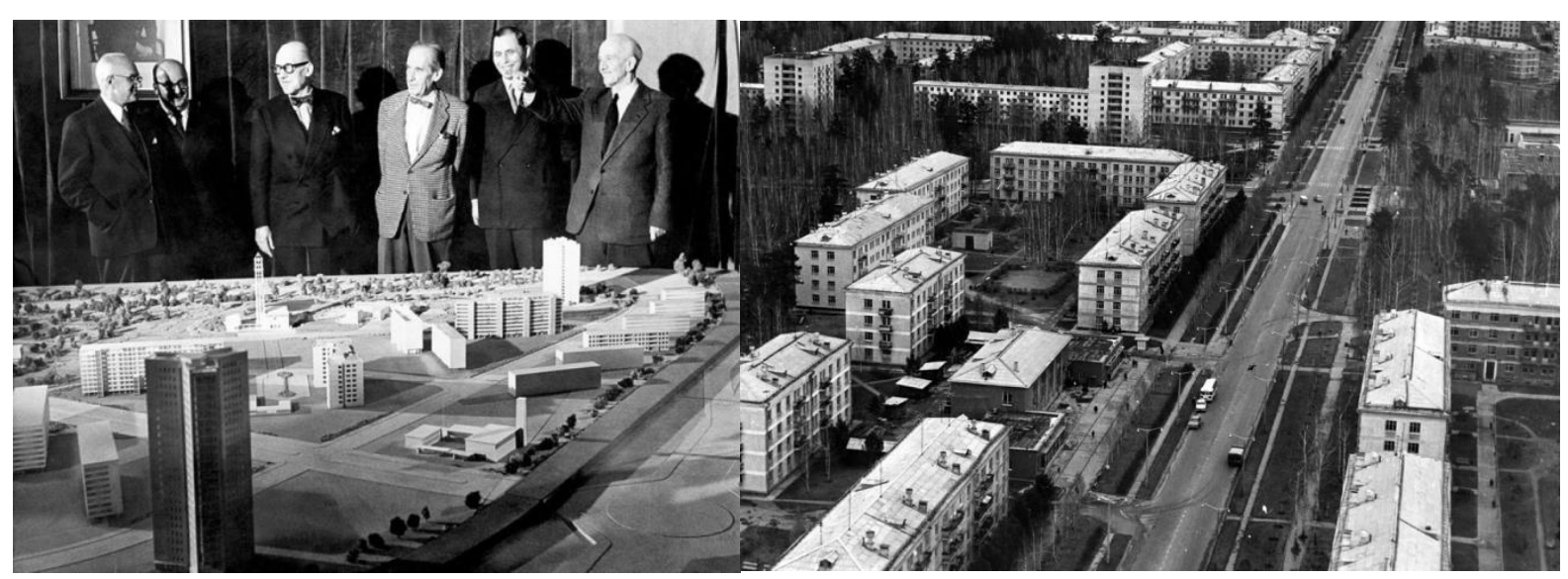

Рис. 3. В. Гропиус. Квартал в районе Ганзы Рис. 4. Новосибирский Академгородок

Проблемам развития проектно-строительного комплекса СССР в городах центра России и на сибирских окраинах в 60-70-е годы (когда 
описанные выше тенденции однозначно приобрели тотальный характер), посвящена отдельная, но не следующая глава данного исследования: ведь и сама история бескомпромиссной борьбы архитектурных тенденций и концепций, начавшаяся в период революционного слома российской исторической политической системы в 1917 году, характеризуется не совсем последовательной сменяемостью вех и направлений движения.

Сейчас же есть необходимость вернуться в предшествующий период 40-50-х годов XX века, чтобы наиболее полно, в двукратном сравнении, показать разницу стилей, принципов и результатов воздействия классической художественной и рациональной индустриальной школ на внешний облик и содержательное наполнение архитектурно-градостроительной среды и этапы трансформации нормативно-правовой базы российского градостроительства.

\section{Глава 3. Принципы классицизма и градостроительные замыслы 50-x.}

В первые послевоенные годы сохранялись высококвалифицированные кадры и академический настрой старой архитектурной школы: как в теоретическом осмыслении основ профессиональной деятельности, так и в строительной практике: при восстановлении разрушенных городов была востребована преемственная система классических архитектурноградостроительных ценностей: соблюдались принципы композиционно организованной, ансамблевой городской застройки, создания выразительных силуэтных панорамных решений на основе расстановки композиционных акцентов (доминант) и «пауз»: ритмичного, почти музыкального по восприятию чередования открытых и застроенных пространств скверов, площадей, улиц и набережных; уделялось большое внимание художественностилистическим сочетаниям и пропорциональной гармонии новой и исторической застройки, ансамблевой сомасштабности и стилистическому единству пространственного комплекса или линейного ряда смежных зданий, значимости архитектурных членений зданий и декоративных элементов и их смысловой доступности, соразмерности человеку, и т.д.

Но самое главное, что проектировавшие здания и реконструировавшие города архитекторы, бывшие признанными мастерами и исключительно творческими личностями, многие из которых вкусили и развивали ранее новаторские принципы конструктивизма 20-х (братья Веснины, Гинзбург и др.), а другие твердо отстаивали архитектурную классику (Жолтовский, 
Алабян и др.), смогли тем не менее работать в единой команде, подчинить свою яркую индивидуальность общему проектному замыслу (в случае с высотными зданиями и генпланом Москвы) и органично вписывать по стилю и пропорциям новые постройки в сложившиеся ранее уличные развертки фасадов или ансамбли площадей и набережных.

Эти принципы наиболее ёмко сформулированы, на наш взгляд, в статье В.Л. Глазычева 1979 года «О градостроительном такте, профессиональной культуре и творческой свободе»: «Никто не подвергает сомнению суверенное право архитектора на собственное понимание профессиональной задачи, на самовыражение в процессе ее решения. Но ведь, в отличие от живописца или поэта, архитектор не просто отдает свое произведение на суд людям, он еще и навязывает его им как трудноустранимый факт бытия. В архитектуре, как нигде, может быть, свобода творчества есть осознанная необходимость свободного выбора, и вот то, из чего осуществляется выбор, и то, как он осуществлен и осознан, определяет меру обоснованности решения, которую числом не выразишь, но которая опознается сразу и точно» [5].

Вместе с тем, абсолютно понятно, что наряду с выбором, который делает сам архитектор на основании профессионального видения, мировоззрения и этических норм, исходные, регулирующие и результирующие его творчество факторы этим не ограничиваются. И уникальность послевоенной ситуации в архитектуре СССР (на самом деле, в очень краткосрочный период: 1945- 1954гг.), заключалась именно в совпадении вектора преемственного развития классических архитектурно-градостроительных традиций, проповедовавшегося мастерами-академиками как основной принцип в условиях тотальной реконструкции, послевоенного восстановления и развития крупных исторических городов и одномоментного строительства новых малых городов при промышленных предприятиях (преимущественно оборонного характера) на всей территории страны, - с политическими установками руководства правящей КПСС, личными познаниями ее вождя И.В. Сталина и его вкусовыми пристрастиями к монументальной классике [14] - настолько обширными, что это позволило ему лично участвовать в корректировке первоначальных проектных вариантов и согласовывать итоговый вид, символику, планировку и эскизы интерьеров всех девяти «высоток» первой очереди строительства, начатого в 1947 году. 


\section{ИННОВАЦИОННОЕ РАЗВИТИЕ НАУКИ: ФУНДАМЕНТАЛЬНЫЕ И ПРИКЛАДНЫЕ ПРОБЛЕМЫ}

Этот период, несмотря на его кратковременность и огромный масштаб решаемых задач, принес очень много положительных результатов для советского градостроительства. Главное, конечно - невероятные масштабы и темпы восстановления разрушенных в войну городов и населенных пунктов; их мостов, улиц, площадей, набережных, скверов. И качество градостроительных и архитектурных решений в комплексной, зачастую ансамблевой застройке важнейших элементов и рядовых фрагментов городской среды - оставшееся на века, сопоставимое с архитектурными шедеврами дореволюционного времени.

Что касается основных, принципиальных отличий от современной архитектуры и градостроительства - это, наряду с эстетико-стилистической гармоничностью архитектуры отдельных зданий, безусловно, первоочередное внимание к объемно-пространственной градостроительной композиции, созданию комплексных (разных по принципам организации и размещения: пространственных, закрытых, линейных, панорамных и др.) архитектурных ансамблей, и специально ставившиеся в генплане города и решаемые при его реализации концептуальные задачи формирования выразительного силуэта и облика города: как единого целого, так и его частей.

В редакционном введении сборника теоретических статей 1952 года «Проблема ансамбля в советской архитектуре» [11], академик К. Трапезников пишет: «Советский архитектор призван проектировать и строить не только отдельные сооружения, но прежде всего целые комплексы зданий, улицы, площади, кварталы, объединенные единством идейно-художественного замысла и строительно-технического выполнения. Творческая разработка рассматриваемой проблемы охватывает вопросы ... о роли высотных зданий в формировании ансамбля города, традициях и новаторстве в построении ансамбля, распространении начал ансамбля не только на центральные части города, но и на рядовую застройку жилых кварталов...»

Необходимо отметить, что градостроительное проектирование этого периода базировалось на серьезных архитектурно-искусствоведческих и теоретических наработках в области анализа пространственной композиции исторических населенных пунктов и их центров (острогов, кремлей, крепостей), принципов размещения и организации исторических религиознообщественных комплексов. 
Наиболее характерный, выразительный и масштабный пример такого преемственного градостроительного решения - комплекс высотных зданий Москвы 50-х годов. В их проектировании и расстановке в композиционных центрах - важнейших точках городской ландшафтно-планировочной структуры Москвы (рис.5,6), советскими зодчими были преемственно учтены принципы и градостроительные приемы народной и профессиональной архитектурных школ.

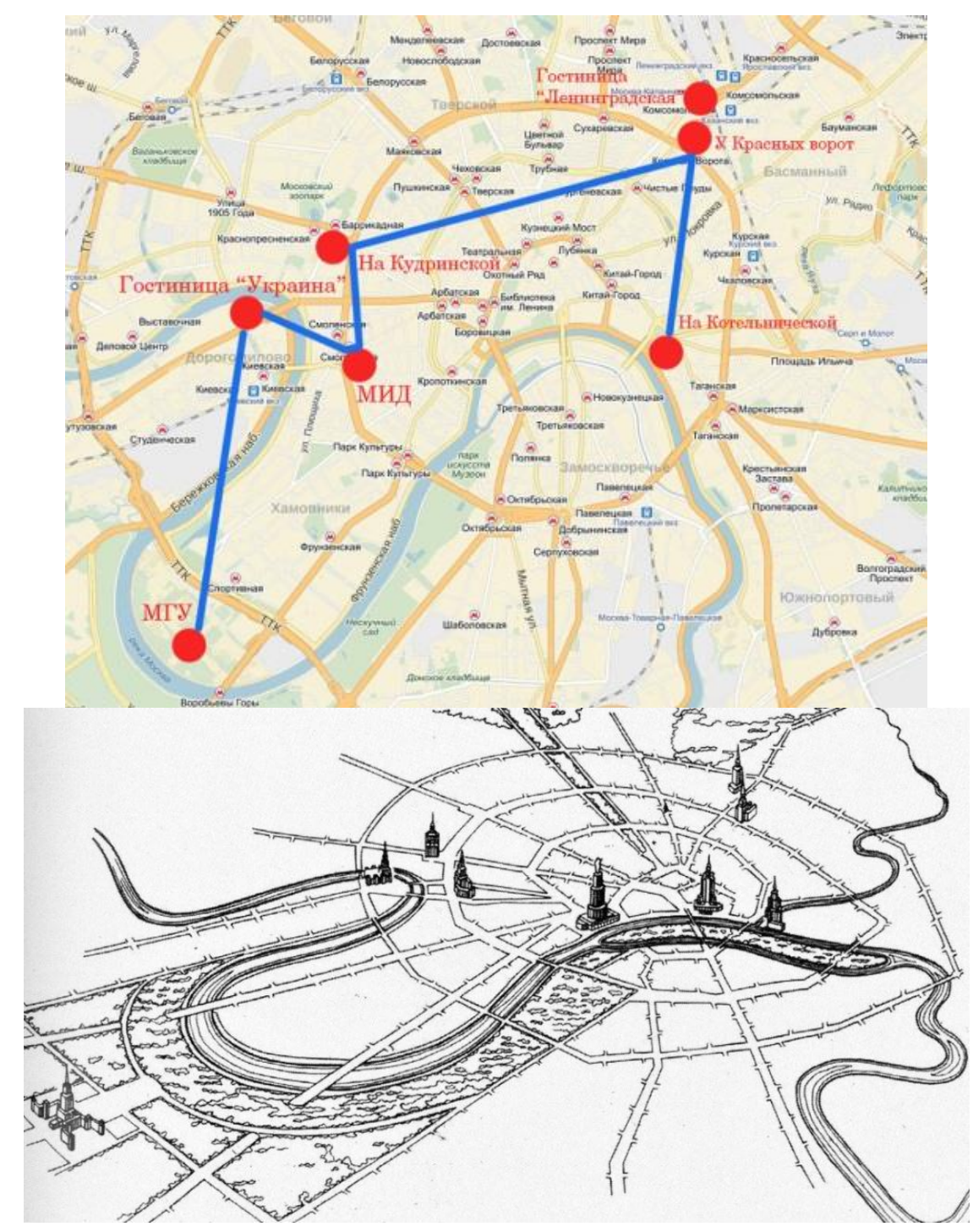

Рис. 5, 6. Схема размещения в Москве построенных и планировавшихся «сталинских» высоток на стратегических высотных отметках, пересечении важнейших планировочных осей и изгибах Москвы-реки 
В качестве подтверждения постулатов данного положения приводим иллюстрации (рис.7-9) из научных работ, посвященных исторической преемственности в формировании архитектурно-градостроительных ансамблей русских городов, выполненных известными исследователями архитектурно-градостроительной композиции: Ю.С. Ушаковым, Л.И. Кирилловой, Ю.А. Егоровым $[13,8,10]$.
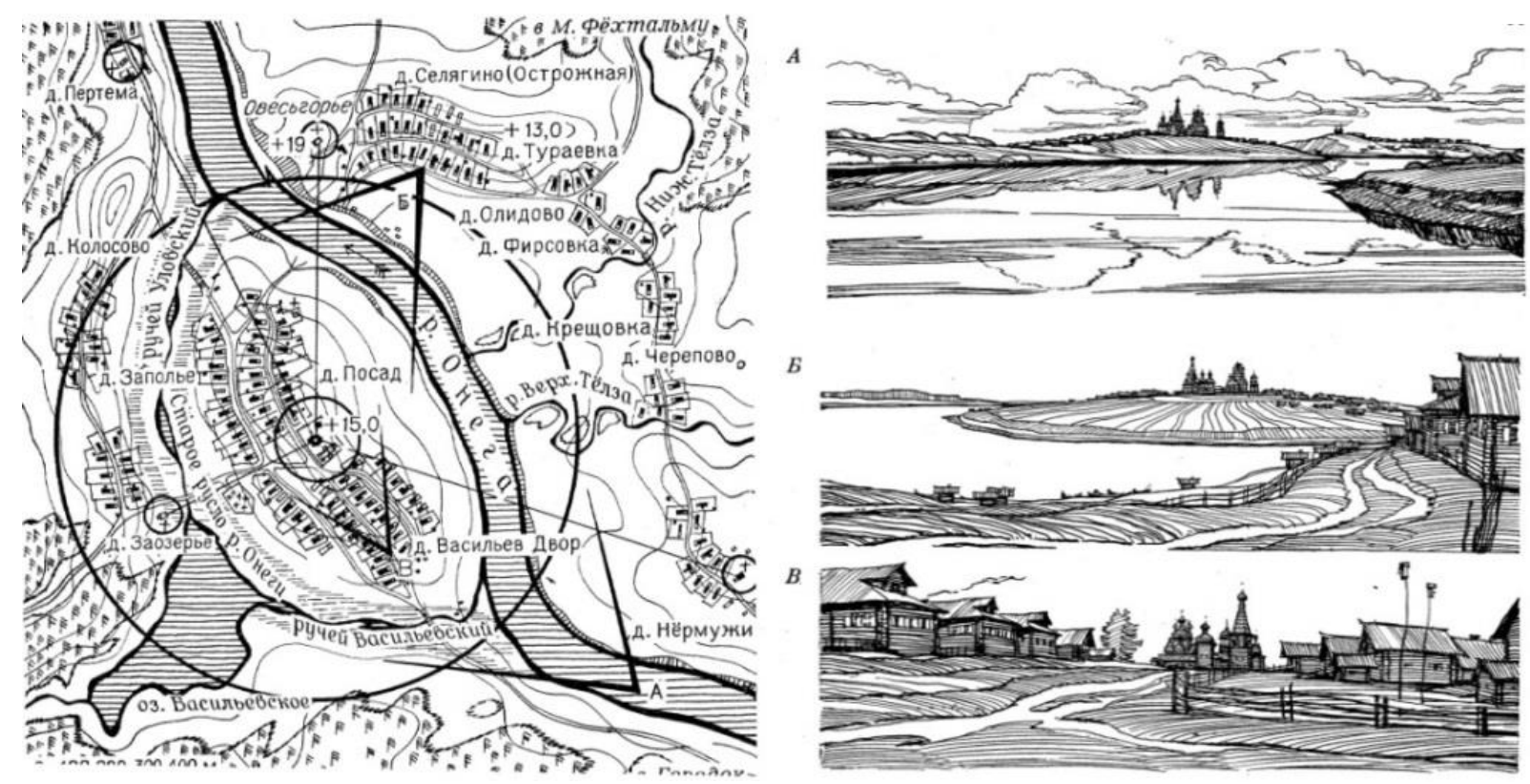

Рис. 7. Село Турчасово Архангельской области [13]. Видовые точки и секторы, ситуационная типология приемов размещение архитектурных доминант: на излучине реки и/или на господствующих высотах (A, Б), в точке перспективного схода застройки улицы (B) 

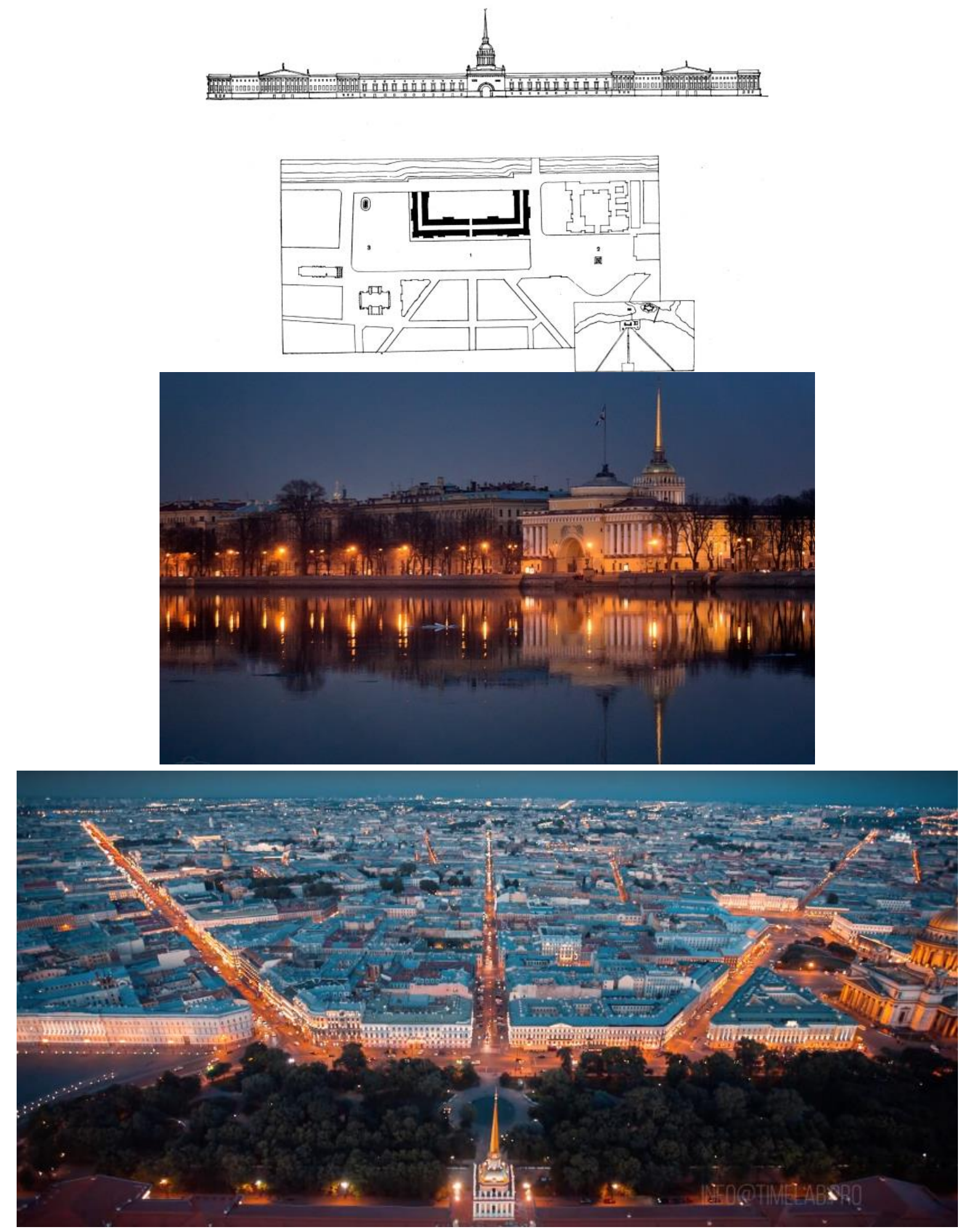

Рис. 8. Работа профессиональных мастеров (арх. И.К. Коробов, А.Д. Захаров) Адмиралтейство в г. Санкт-Петербурге [8] и современная композиционно-пространственная роль здания (фото Яндекс) 

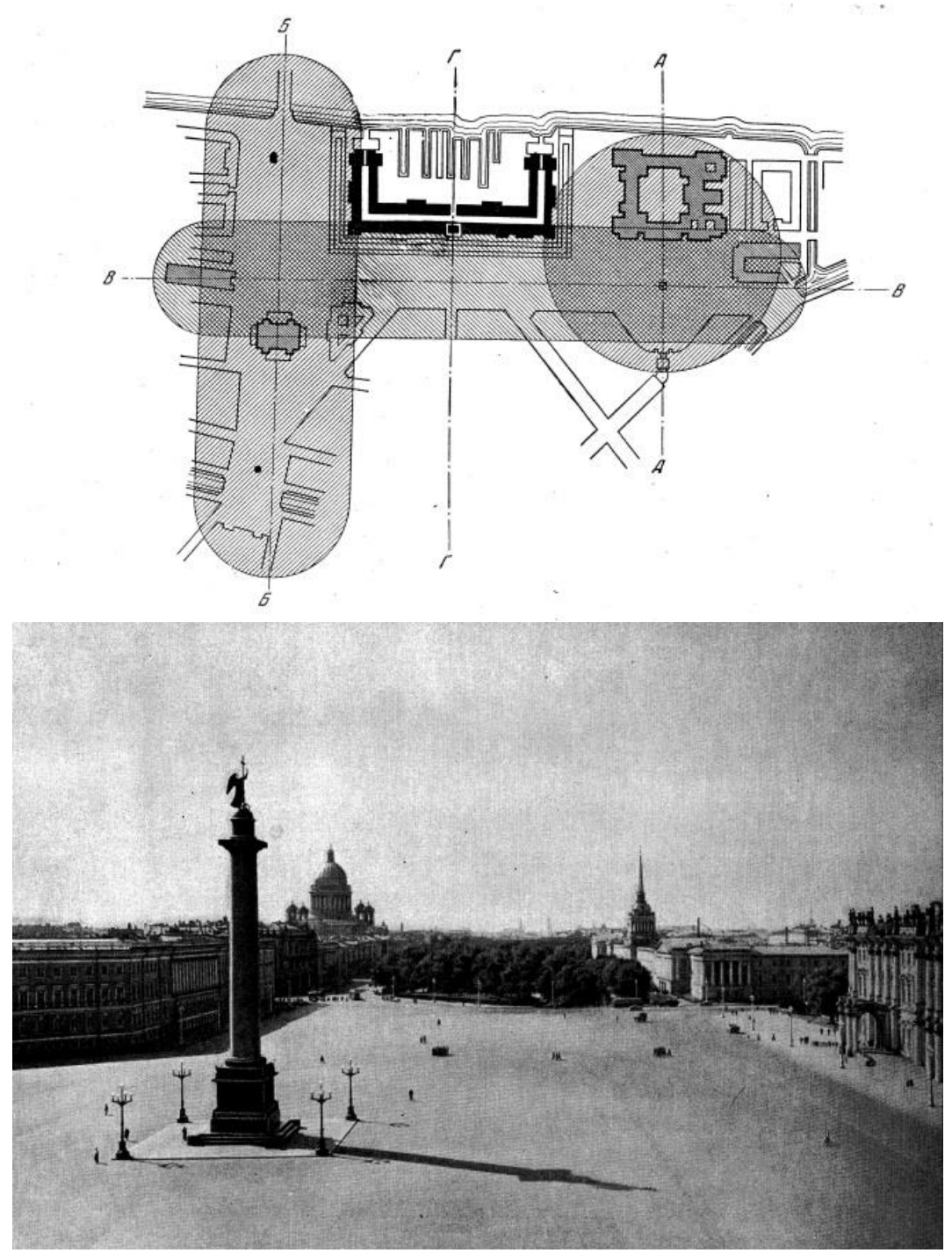

Рис. 9. Схема взаимосвязанной композиционной «работы» пространств Дворцовой Адмиралтейской, и Исаакиевской площадей в г. СанктПетербурге - единого архитектурно-градостроительного ансамбля, созданного русскими и итальянскими архитекторами [10]. Каждая площадь фиксируется видовыми композиционными доминантами; сформирована уникальная система образной ориентации

На представленных выше схемах и фотографиях продемонстрированы основные, исторически сформировавшиеся приемы размещения градостроительных доминант с учетом особенностей ландшафта и планировочной структуры городов и поселений; их роль в объемно-пространственной композиции, создании выразительного силуэта и облика города. 


\section{ИННОВАЦИОННОЕ РАЗВИТИЕ НАУКИ: ФУНДАМЕНТАЛЬНЫЕ И ПРИКЛАДНЫЕ ПРОБЛЕМЫ}

При этом не столь важен размер территории и количество проживающих в том или ином населенном пункте людей, да и, по большому счету, национальные архитектурные традиции: во многих европейских государствах и русском народном градостроительстве эти принципы расстановки важнейших объектов и комплексов, будь то острог, монастырь, храм, кремль, дворец короля или рыцарский замок, можно охарактеризовать как идентичные.

И во всех случаях гениальных или просто удачных результатов, первичными являются исходная транспортно-планировочная структура, культурно-историческая и природная среда - или, по-современному, «культурный ландшафт» - то есть то, что в нормальных архитектурных школах называется профессионально-емким понятием «ситуация».

Как показано на вышеприведенных примерах, также не имеет значения происхождение данных композиционно-планировочных принципов расстановки и взаимной увязки градостроительных акцентов (народное это зодчество или профессиональное образование автора): главное, что они узнаваемы, интуитивно понятны как зодчему, так и простому обывателю, и уже поэтому требуют преемственного, обязательного, установленного в профессиональных кодексах и нормах, освоения и применения в современном российском градостроительстве.

В свете вышесказанного и представляется необходимым остановиться на самом удачном и комплексно реализованном примере освоения в России $\mathrm{XX}$ века научно-градостроительных теорий и азов практики русского народного зодчества - строительстве Высотных зданий Москвы 50-х годов.

Эти грандиознейшие и предвосхитившие будущее с точки зрения инженерно-конструкторской мысли, а также богатейшие по тектонике объемов и пластике фасадов, художественным интерьерным решениям и материалам сооружения, мы в контексте темы работы рассмотрим лишь с позиций градостроительной композиции, а именно - их роли как композиционно-структурных доминант, элементов возрождения утраченного в процессе длительной бессистемной застройки исторического высотного силуэта, облика и образа Москвы.

Поскольку авторами не ставится цель подробного описания всего комплекса Высотных зданий (самое подробное и объективное, энциклопедическое освещение этой темы приведено в работе искусствоведа 
Н. Кружкова «Высотки сталинской Москвы. Наследие эпохи» [14]), основные силуэтно-композиционные принципы и приемы, использованные сталинскими зодчими в этом грандиозном градостроительном проекте, можно тезисно представить по трем реализованным проектам из представленной ниже таблицы (рис.10), принципиально отличающимся по архетипу места (градостроительной ситуации): №№ 1,4,6:

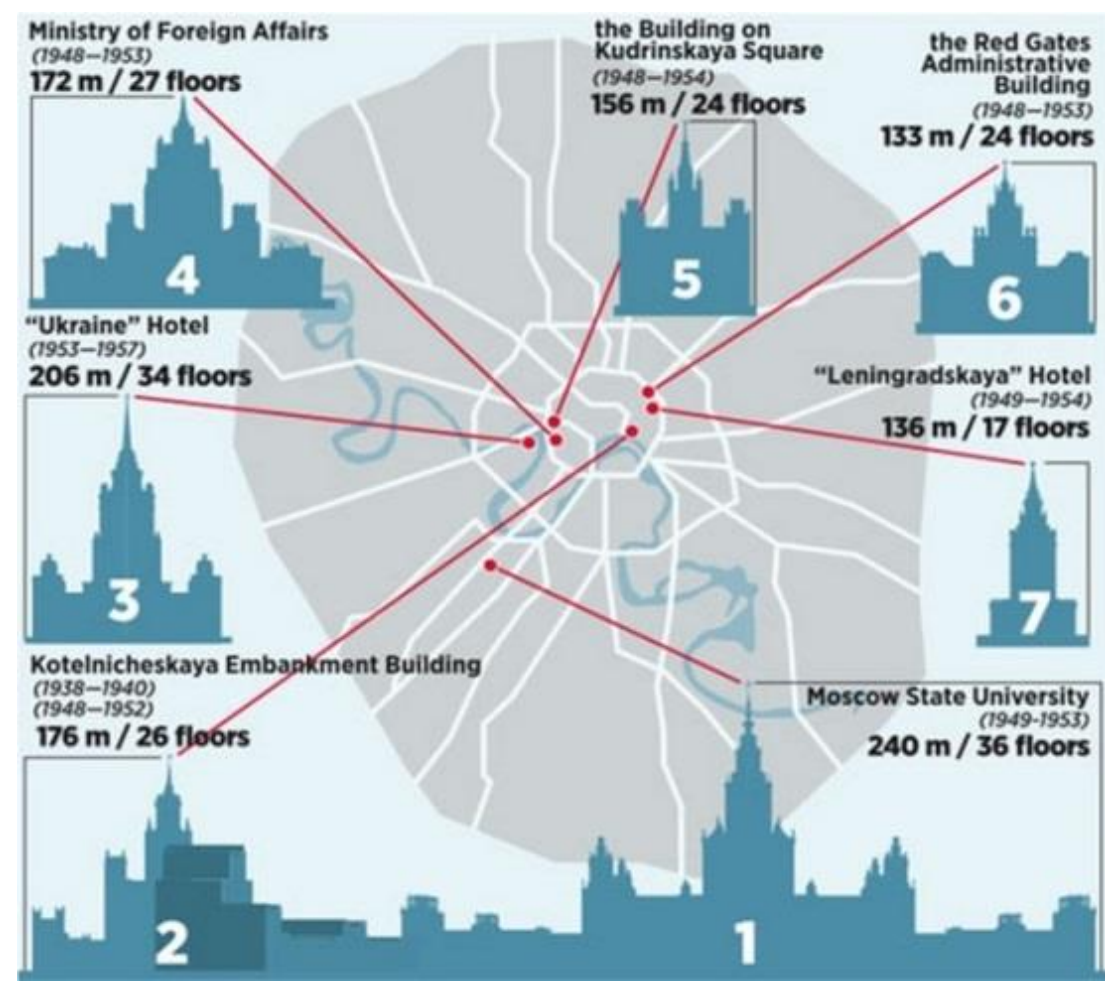

Рис. 10. Схема расположения построенных высотных зданий Москвы [15]

№1 Здание МГУ им. М.В. Ломоносова на Ленинских горах (1949-1953), puc.11-14. Архитекторы Л. Руднев, С. Чернышев, П. Абросимов, А. Хряков; главный конструктор В. Насонов [9].

Условный композиционно-пространственный тип доминанты фиксация ландшафтной возвыпенности (исходная точка главной планировочной оси). 

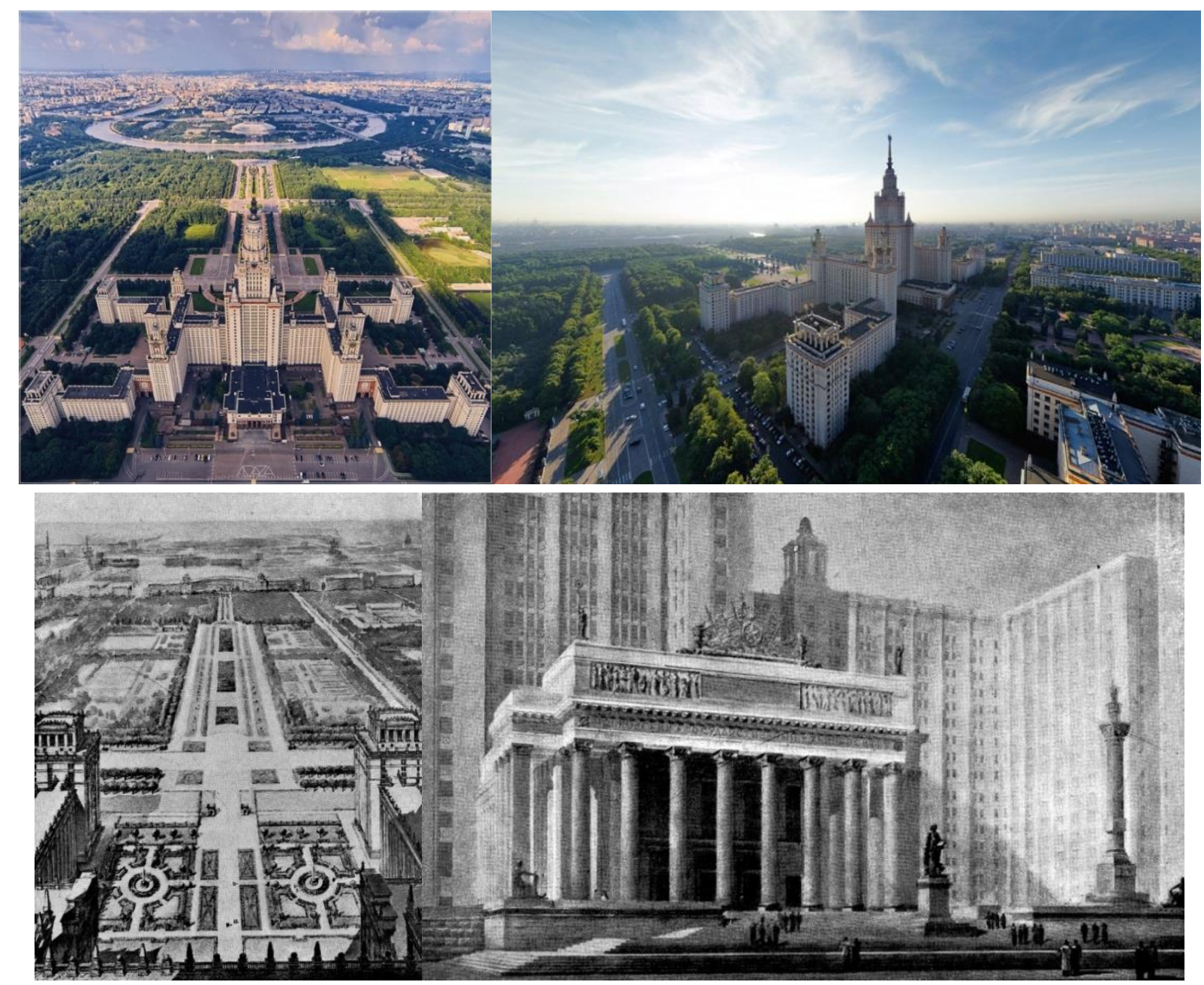

Рис. 11 - 14. Комплекс зданий МГУ: проект и современное состояние.

\section{Градоформирующая роль в качестве силуэтной} композиционной доминанты

Университетский комплекс является самым грандиозным из сооружавшихся высотных зданий объектом: 240м, 36 этажей, самая большая, просто гигантская площадь «пятна застройки» и прилегающего благоустройства кампуса - сквера, решенного в классическом регулярном стиле. Еще в XIX веке предпринимались попытки строительства на этом возвышенном участке городского ландшафта (в военной терминологии «господствующая высота») храма в честь победы над Наполеоном в 1812 году, однако этот замысел не был реализован.

Не разгадывая основную цель и авторский замысел строительства, просто цитируем первоисточник 1953 года [9, с.7]: 


\section{ИННОВАЦИОННОЕ РАЗВИТИЕ НАУКИ:

«Этот величественный комплекс в своем архитектурном образе призван достойно отобразить самую передовую в мире советскую науку. Сооружением университета разрешается крупнейшая градостроительная задача планировки и объемно-пространственного решения юго-западного района Москвы. Университетский комплекс с его мощным объемом и богатым величественным силуэтом явится организующим началом всего окружающего пространства нового района. Территория университета связана с основными магистралями юго-западного района города и тянется до бровки откоса Ленинских гор, откуда будут оборудованы спуски к реке...»
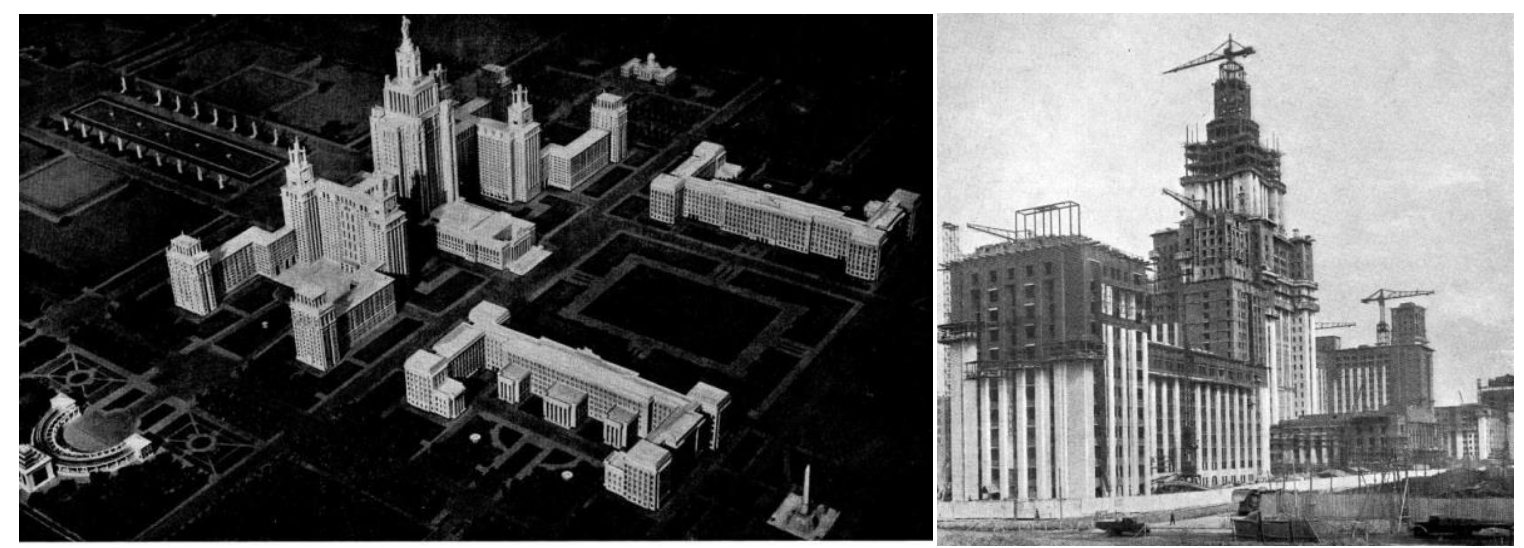

Рис. 15, 16. Макет комплекса МГУ (проект 1948г.) и строительство главного корпуса

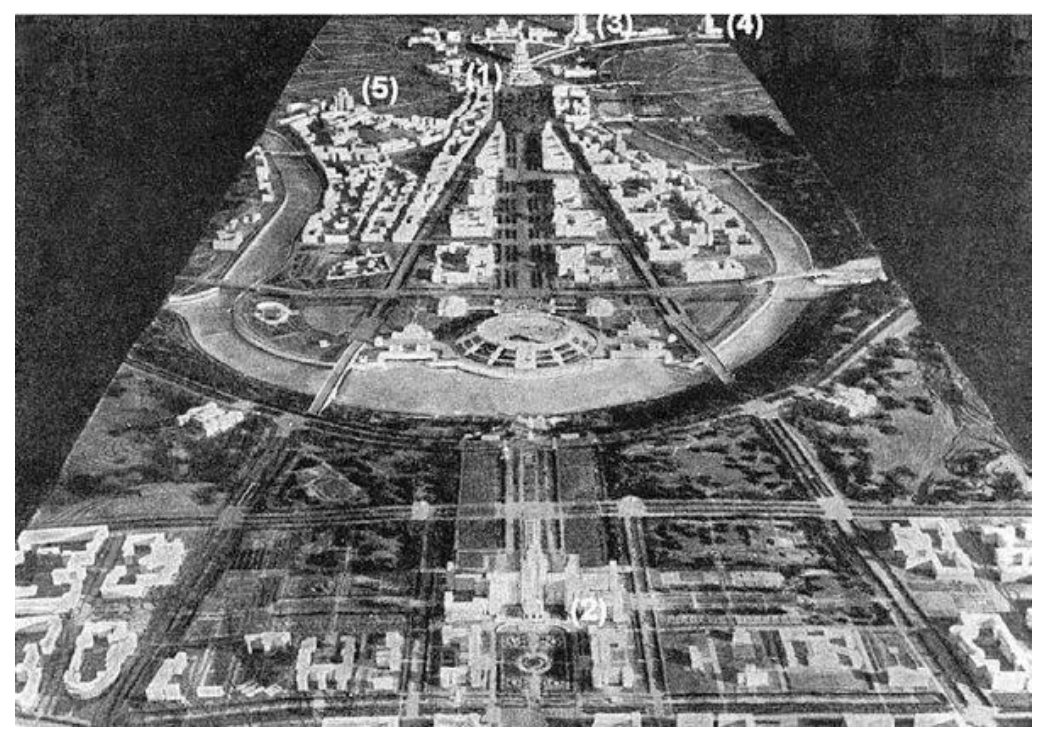

Рис. 17. Макет к одному из проектных предложений по застройке центрального района г. Москвы [14]. Вид со стороны Ленинских гор 


\section{ИННОВАЦИОННОЕ РАЗВИТИЕ НАУКИ: ФУНДАМЕНТАЛЬНЫЕ И ПРИКЛАДНЫЕ ПРОБЛЕМЫ}

И далее, описание Н. Кружкова: «Если продолжить ось симметрии университетского комплекса на Ленинских горах до Кремля, то статуя В.И. Ленина, планировавшаяся к установке на башне Дворца Советов, оказалась бы именно на этой оси и была бы устремлена в сторону Кремля. Макет был так велик, что помещался только в Мраморном зале Московского Совета. Макет давал зримое представление о том, как высотные здания вписываются в силуэт центра Москвы» [14]. Такому способу и открытости общественного представления проектных решений сейчас можно только позавидовать. Сравнивая отображенные на макете композиционно-пространственные идеи авторов с эскизным проектом (рис.13,14) и современный вид от Университета в сторону центра - Кремля (рис.11), можно с уверенностью сказать, что в целом градостроительное проектное решение с расстановкой высотных доминант на главной оси города и на важнейших узловых сочленениях ландшафтно-транспортной планировочной схемы - со сгущением вертикальных акцентов к центральному ядру города, - было абсолютно верным и обоснованным. Была предложена внятная композиционная система визуально-пространственной ориентации и ландшафтно-планировочной организации, то есть выявленного объемного структурирования городской среды, по ряду причин оставшегося незавершенным. При этом, судя по архитектурно-художественному облику отдельных нереализованных объектов (в первую очередь - Дворца Советов по проекту Б. Иофана и административного здания в Зарядье архитектора Д. Чечулина); игнорированию в их гипертрофированных габаритах и масштабных членениях исторически сложившегося средового контекста, следует констатировать, что сама судьба оберегла столицу России от непоправимой градостроительной ошибки: то, что можно строить на периферии, на свободных площадках, разрушило бы относительно мелкую квартальную структуру застройки, алгоритм ритмической пульсации пространств улиц, площадей и скверов, колорит московской архитектуры, и уничтожило бы неповторимый облик центра Москвы: 


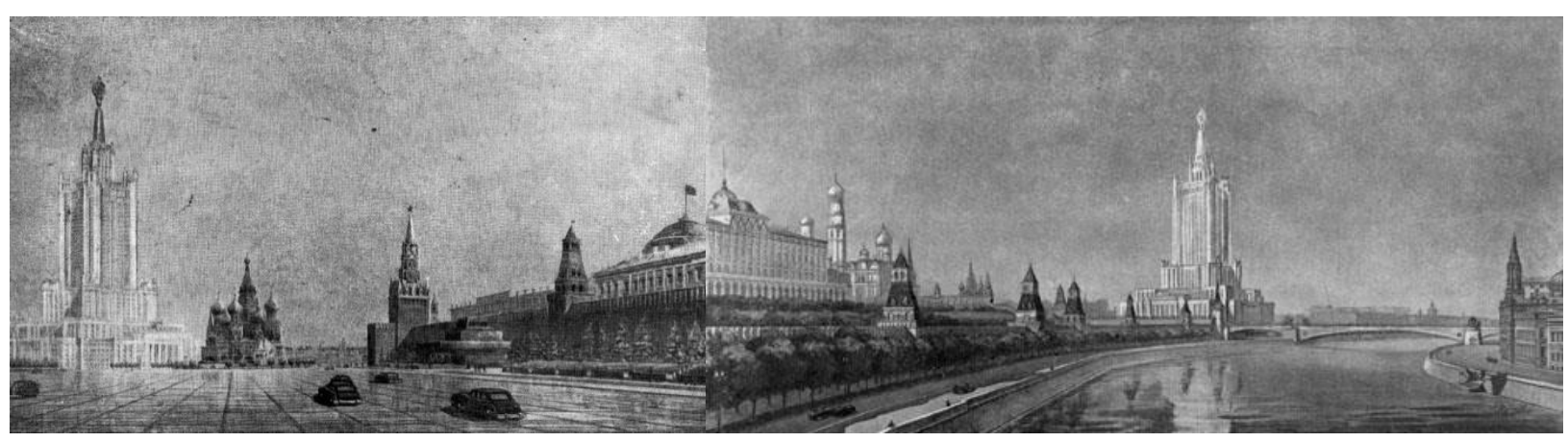

Рис. 18, 19. Проект здания в Зарядье. Грубое игнорирование принципов архитектурно-градостроительной преемственности, разрушение пропорционального строя силуэта города: чужеродный несомасштабный объект [9]

Таким образом, Университет - единственный реализованный проект высотных зданий, Москвы 50-х годов, где удалось наиболее полно и эффективно воплотить в жизнь замысел архитекторов, не только создав композиционно-пространственный центр, ядро района, но и построив величественное здание с самым благородным функциональным содержанием (образование молодежи), комплексно благоустроив всю прилегающую территорию. Здесь (рис.11,12) сбылись слова песни «Ленинские горы», написанной и исполнявшейся во время строительства комплекса МГУ и посвященной его строителям, многие из которых впоследствии сами учились в построенном ими храме науки:

"Сейчас пустынны Ленинские горы,

Но флаги стройки вьются на ветру

Здесь корпуса взойдут до неба скоро,

Сюда придут студенты поутру...» (Стихи Е. Долматовского)

№4. Здание гостиницы «Украина» на пересечении Дорогомиловской набережной и Кутузовского проспекта (1953-1957), рис.20-22.

Архитекторы А. Мордвинов, В. Олтаржевский; гл. конструктор

П. Красильников [9]. Условный композиционно-пространственный тип доминанты фиксачия ландмафтно-планировочного узла (пересечение путьрека). 

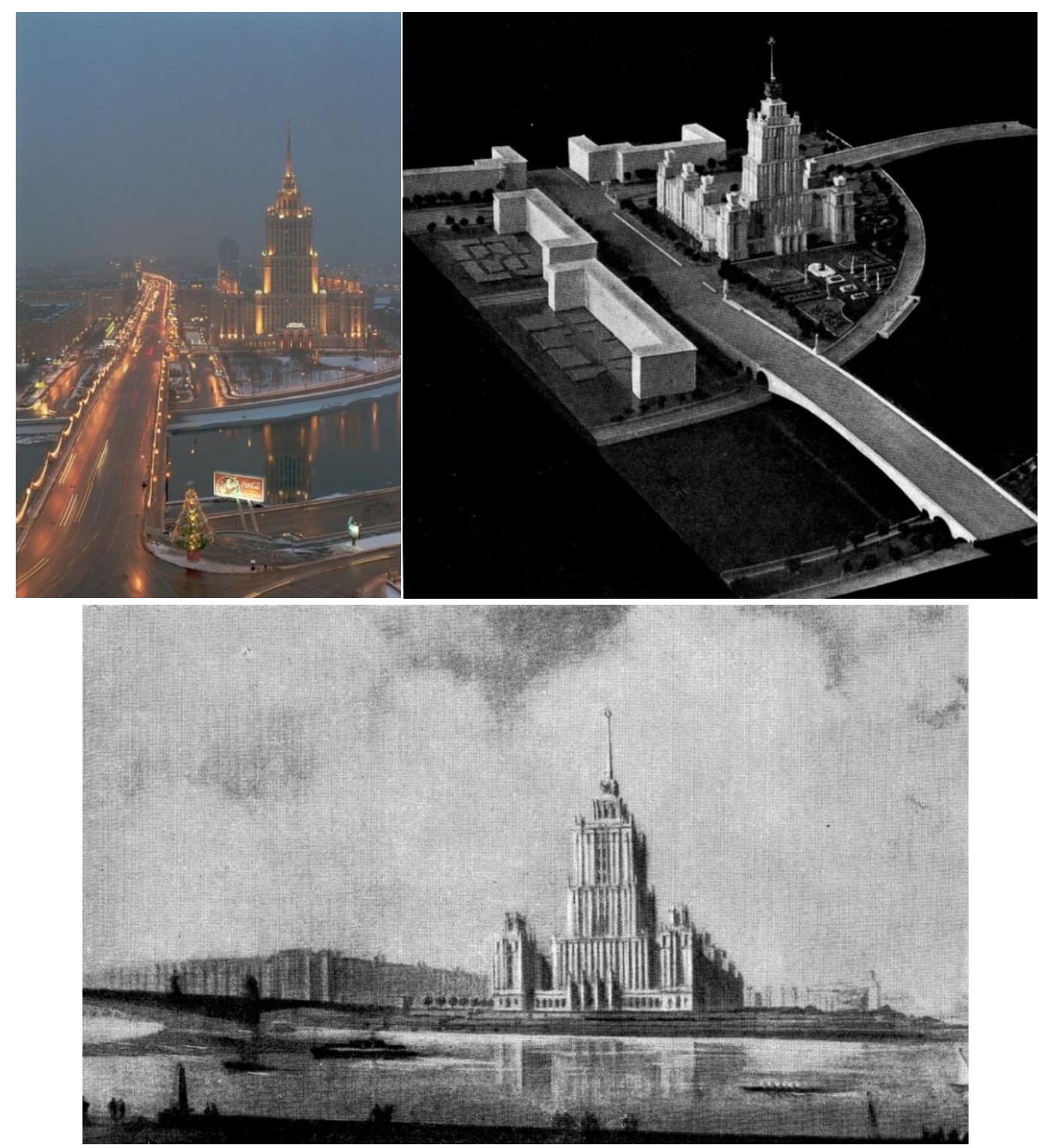

Рис. 20 - 22. Здание гостиницы «Украина» на Дорогомиловской набережной Москвы-реки: современный вид, макет и эскизная панорама с противоположного берега [9]

Здание гостиницы, построенной в 1953 -1957 годах, должно было называться «Гостиничное здание в Драгомилове». Название «Украина» гостиница получила уже при Н.С. Хрущеве (когда была и переименована набережная в им. Тараса Шевченко). В настоящее время относится к сети «Рэдиссон Коллекшн». Как видно из иллюстраций, в данном случае проект также реализован практически в неизменном виде и авторам удалось закрепить доминантой высотного здания с богатым и выразительным силуэтом точку пересечения на плане плавно изгибающейся оси реки и луча 
важнейшей городской магистрали - Кутузовского проспекта. Таким образом, сформировался современный выразительный силуэт данного участка речной панорамы застройки. С учетом одновременного строительства, в непосредственной близости к зданию гостиницы моста, набережной и жилых домов, соразмерных по масштабу и стилистически подчиненных архитектурным формам доминирующего сооружения гостиницы, а также ввиду такого комплексного, продуманного градостроительного подхода, этот структурный элемент городской застройки уже к моменту завершения реализации проекта можно было смело назвать архитектурным (градостроительным) ансамблем.

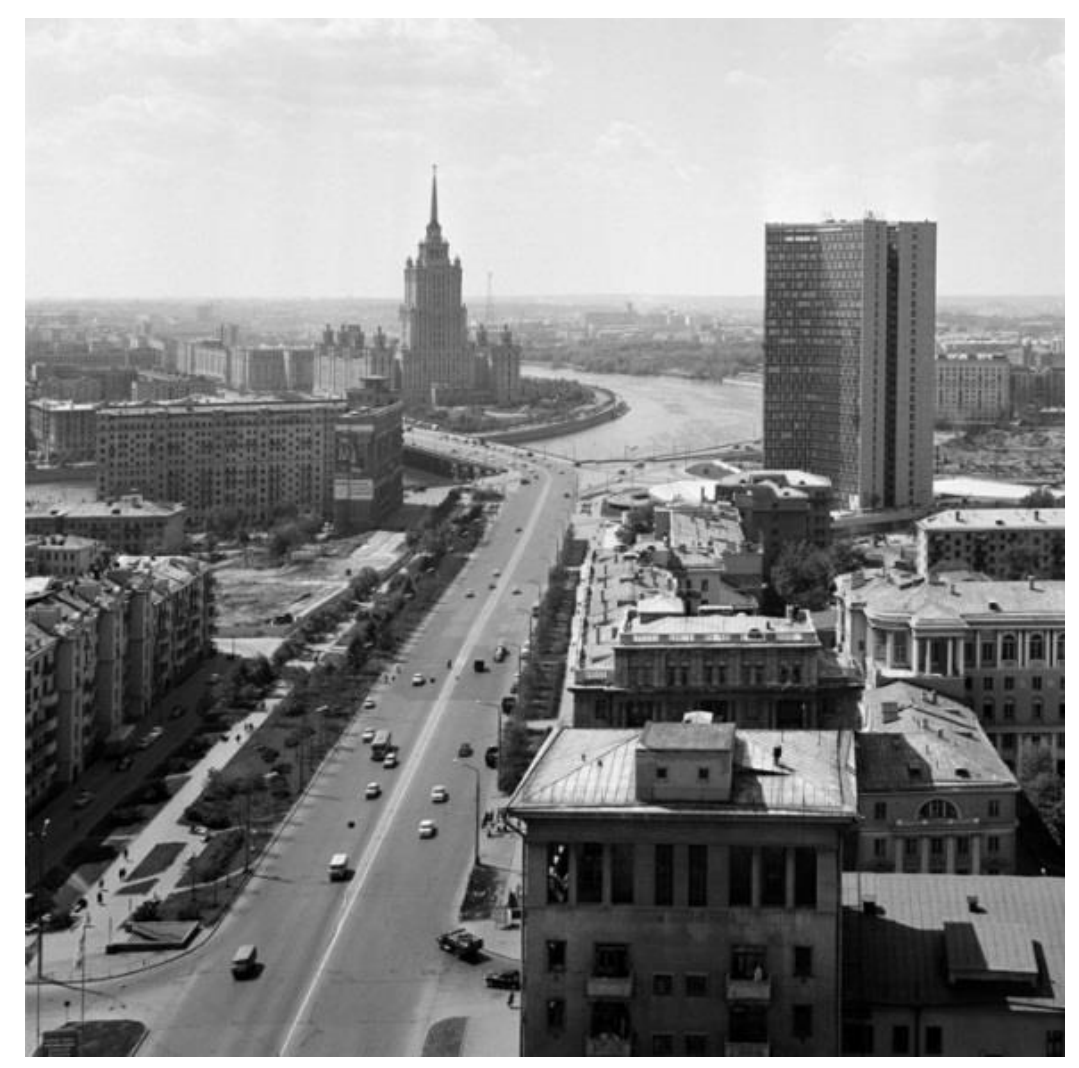

Рис. 23. Различия в силуэтных характеристиках композиционных доминант и степени их органичности в среде (справа - здание СЭВ,1967г.)

Позже, на противоположном берегу реки, вдоль Пресненской набережной, появился целый ряд высотных зданий: здание СЭВ, Дом правительства, Центр международной торговли и, наконец, комплекс МоскваСити, что создало хаос и диссонанс общего облика спорящих между собой объемов и форм (на рис.25 крайняя слева - сталинская высотка на ул. Кудринской). Однако и в этих условиях, благодаря точно сформулированной 
композиционной задаче и гениальной «посадке» на природно-планировочную структуру, здание гостиничного комплекса «Украина» продолжает успешно выполнять свою роль градостроительной доминанты и композиционнопространственного центра - силуэтного пика речной панорамы.

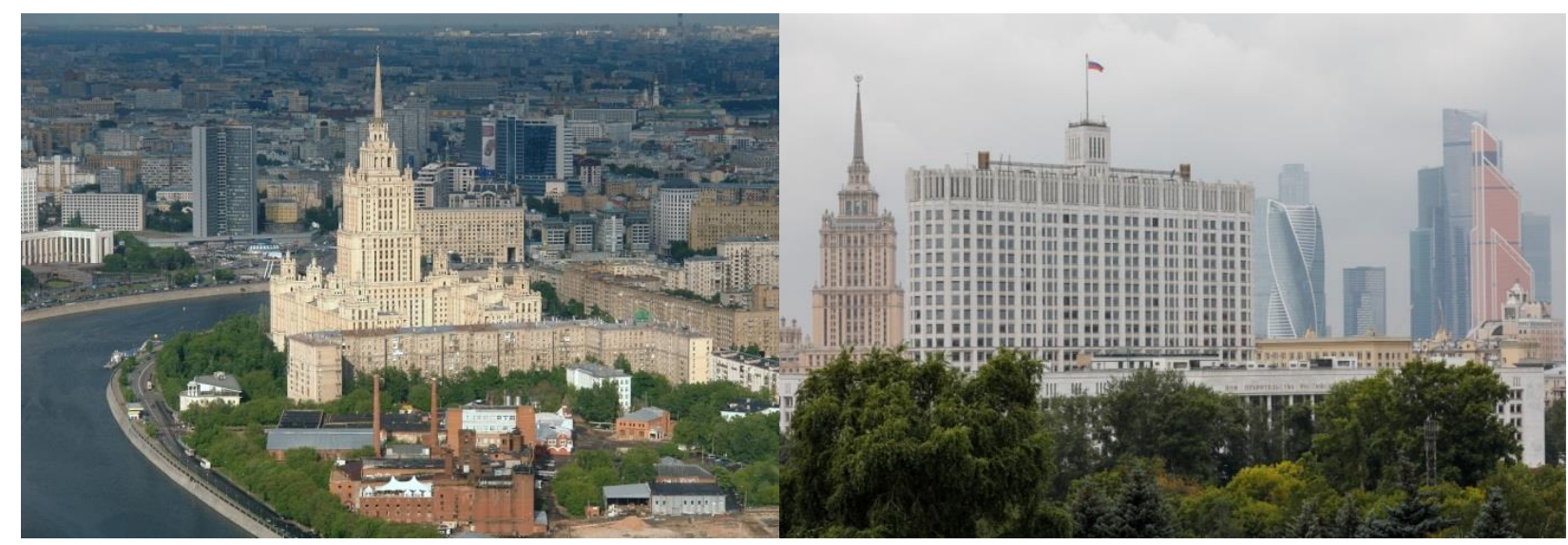

Рис. 24, 25. Вид на здание гостиницы с «тыльной» стороны и вид на панораму противоположного берега (фото ТАСС)

№6. Административно-жилой комплекс над станциией метро «Красные ворота» (1947-1953). Архитекторы А. Душкин и Б. Мезенцев; гл. конструктор В. Абрамов [9].

Условный композиционно-пространственный тип доминанты фиксаиия ландшафтно-транспортного узла (характерная точка возвышенность на Садовом кольие). 


\section{ИННОВАЦИОННОЕ РАЗВИТИЕ НАУКИ:
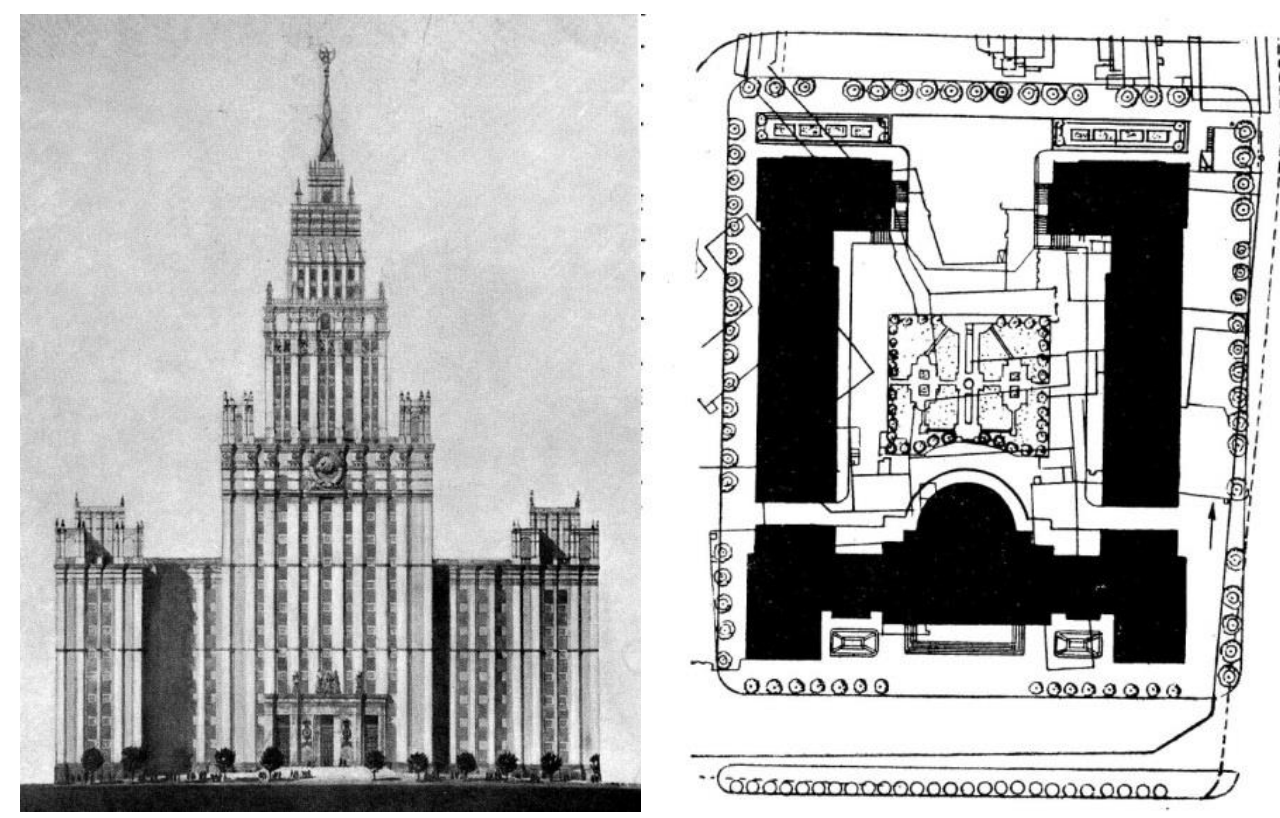

Рис. 26, 27. Главный фасад здания и портал с входной группой в метро [9]

В книге архитектора В. Олтаржевского «Строительство высотных зданий в Москве» особенно отмечается градостроительная роль данного объекта как композиционно-визуального ориентира и разбираются архитектурные приемы, с помощью которых создается выразительность и легкость силуэта здания: «Здание стоит на одном из наиболее высоких мест Садовой, и его строгий четкий силуэт, завершающийся шпилем, одинаково хорошо виден и со стороны Комсомольской площади, и на громадном протяжении Садового кольца. Высотная часть здания расчленена ритмически расположенными вертикалями, придающими легкость всей композиции и в то же время отражающими конструктивную сущность современного высотного здания. Центральный объем построен по принципу ярусности, с последовательным уменьшением и облегчением объемов в сечении. Значительная часть высотного объема решена центрично и обеспечивает создание единого впечатления при обозрении его с различных сторон» [9] рис. 28,29 


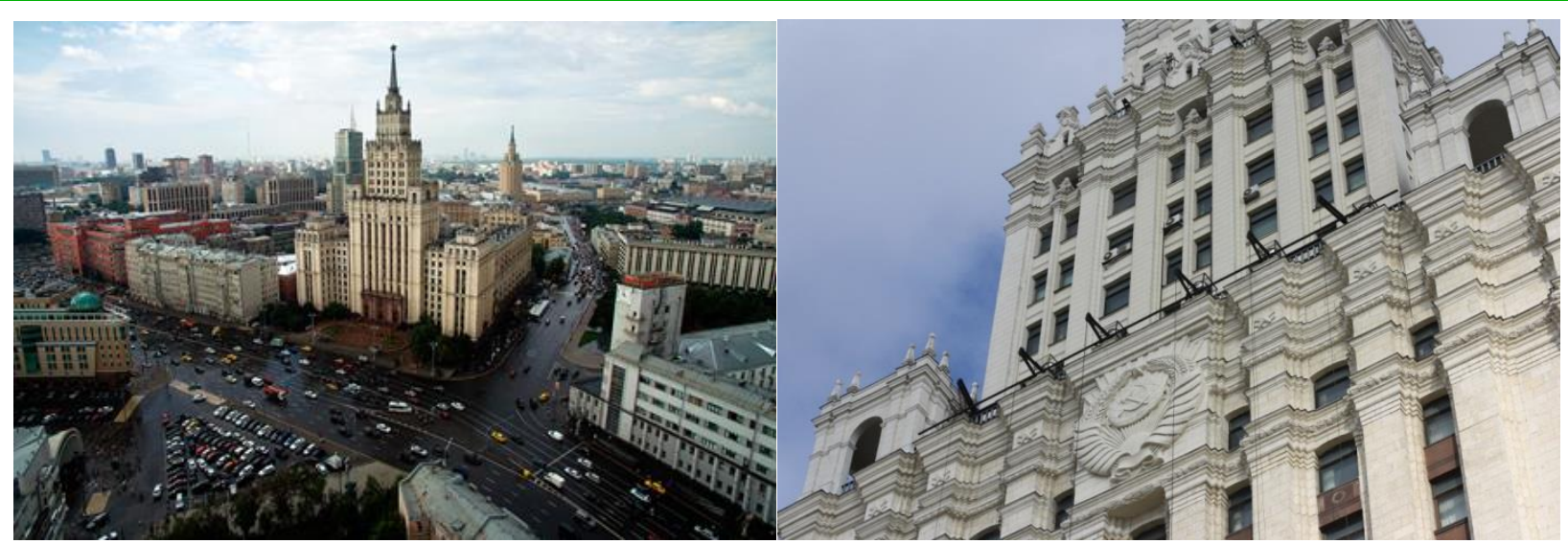

Рис. 28, 29. Градостроительная композиционная роль и пластика фасадов здания (фото Яндекс)
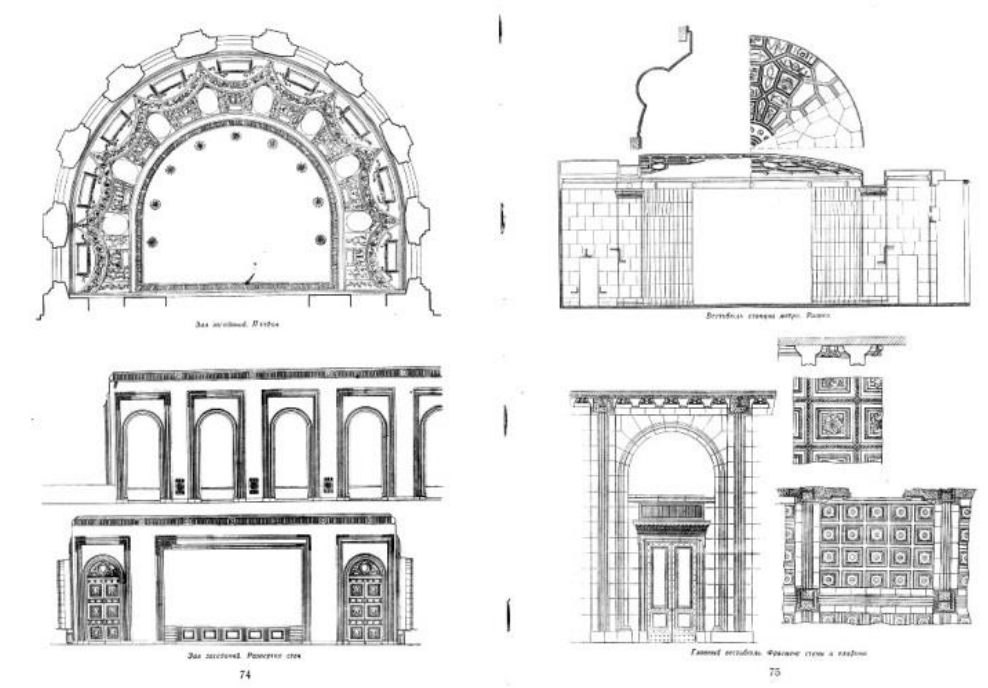

\section{Рис. 30. Интерьеры здания на Садовой}

Разумеется, архитектурно-проектная деятельность 30-50-х годов не ограничивалась строительством уникальных высотных зданий: возводилось очень много достойных жилых и общественных объектов, великолепные школы, театры, стадионы и гостиницы; площади и проспекты этого периода отличаются продуманностью, красотой и величием; создавались многочисленные парки, скверы и другие шедевры ландшафтного искусства.

Просто на примере высотных сталинских объектов, являющихся, в прямом и переносном смысле, самыми видными представителями стиля и эпохи, наиболее отчетливо просматриваются основные функциональные, конструктивные и композиционно-художественные принципы классической архитектуры, творчески освоенной мастерами этого времени, и явственной 
становится ориентация классического советского градостроительства на долговременную историческую перспективу и общественные интересы будущих поколений. Произошедший же в стране политический кризис 19531955 годов для архитектуры, одной из ветвей культуры и искусства, стал понастоящему губительным, поскольку в дальнейшем и до сих пор включительно ведущая роль архитектора, как главного строителя, уже никогда не была так общепризнана, а профессия так уважаема, как до этих событий.

И действительно, проектирование и расстановка на рельефе типовых зданий ограниченной номенклатуры серий, а главное - полученные в результате этой работы антихудожественные и убогие градостроительные решения (рис.31,32) не прибавляли архитектору авторитета вплоть до средины 90-х годов, когда начало возрождаться масштабное индивидуальное архитектурное творчество и появились первые интересные образцы новой архитектуры.

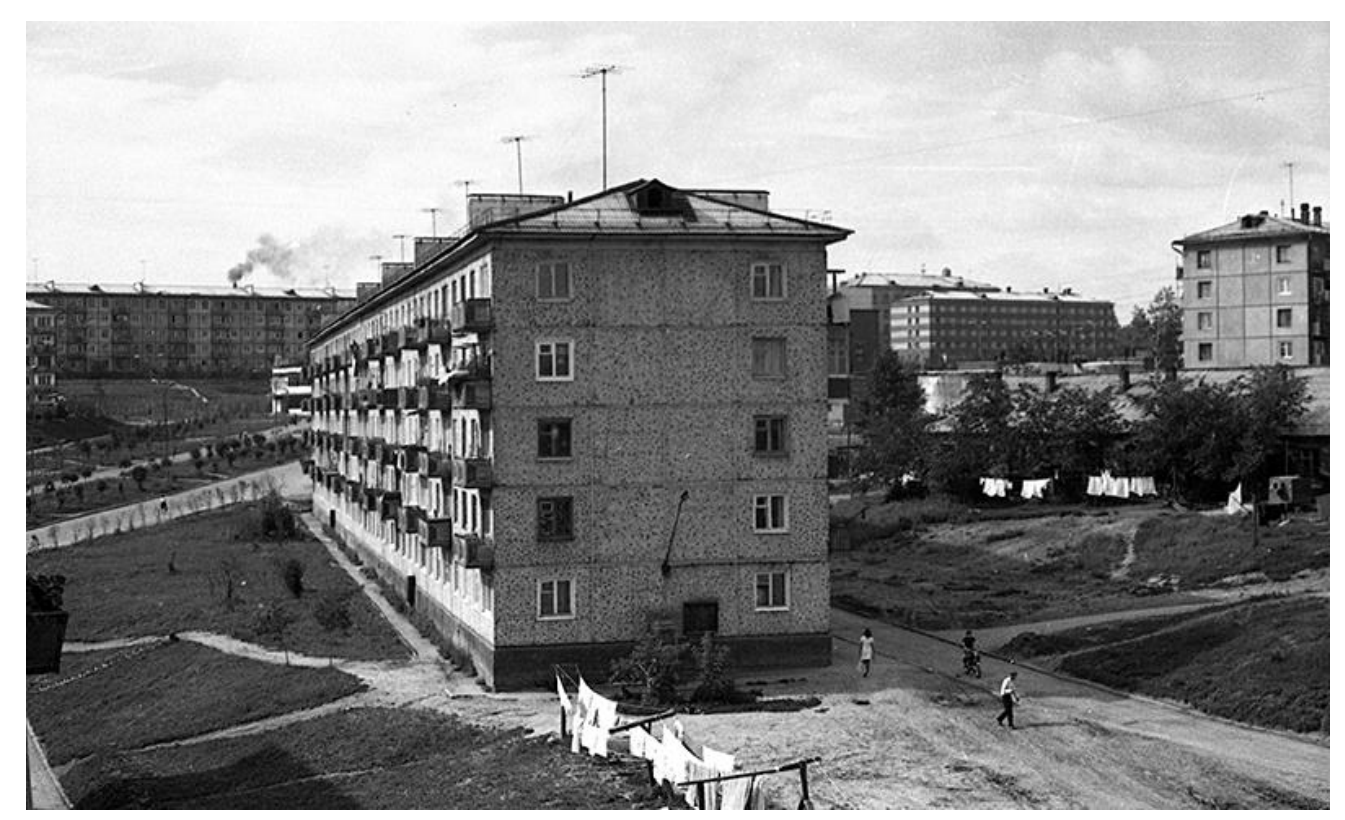

Рис. 31. Иркутск, ул. Байкальская, 70-е годы 


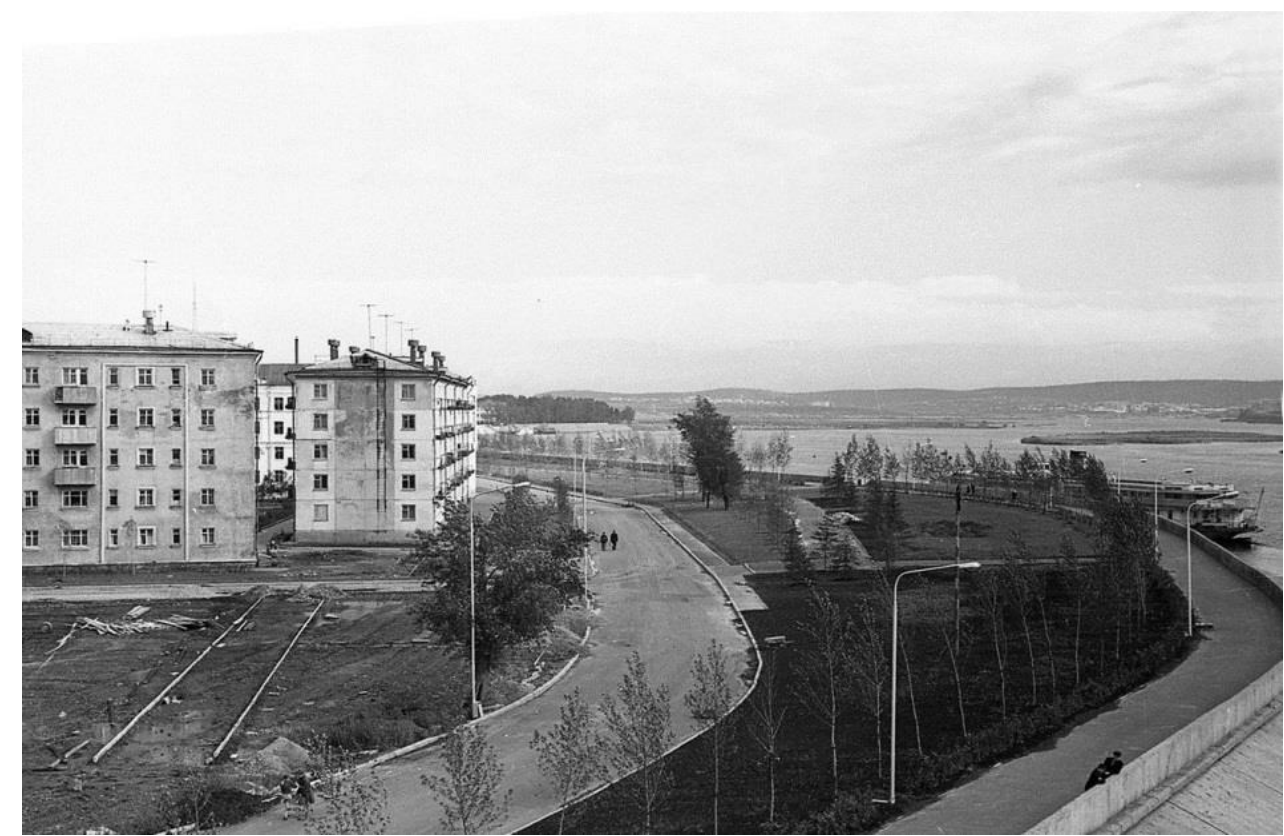

\section{Рис. 32. Иркутск, жилые дома на бульваре Гагарина, 70-е годы}

Подводя итоги первой части исследования, посвященной тектоническим и уникальным историко-культурным переломным процессам в советской архитектуре 50x-60-х годов XX века, становится понятно, что истоки проблем и противоречий современного российского градостроительства, как самостоятельной области научно-теоретических и прикладных знаний и умений, в том числе в нормативно-правовом обеспечении и проектировании, были заложены именно в 60-е годы, - при резком сломе естественного хода преемственного архитектурноградостроительного развития, не несшем, как в 20-е годы, авангардных социалистических идей нового общества и соответствующих теоретических обоснований, а бесцеремонно, нерасчетливо и необдуманно подорвавшем многовековой культурно-смысловой «стилобат» преемственности развития в градостроительстве: единство функционально-конструктивных архитектурнохудожественных и композиционно-пространственных принципов, ранее последовательно реализовывавшихся на урбанизированных территориях страны. Это был нырок на дно и без кислорода, позволявшего вернуться.

На этом Большое академическое градостроительство в России завершилось. И, если не считать пределом возможных архитектурноградостроительных достижений, первоначальные утилитарные результаты по минимальному обеспечению населения благоустроенным жильем путем 
типизации и индустриализации домостроения 60-70-х, тогда же прекратилась социально и гуманитарно-экологически направленная, комплексная и сбалансированная (функционально и эстетически) деятельность по застройке урбанизированных жилых образований и общественных пространств, называемая сегодня модным термином «устойчивое пространственное развитие», легко и естественно перейдя в 90-е годы в плоскость обслуживания узких, сиюминутных частно-капиталистических интересов инвесторов и застройщиков.

В том числе - обеспечивая беспрепятственность этих процессов на государственном и региональном уровне: путем гибко-настроенного градостроительного законодательства и соответствующего процессуального сопровождения застройки градостроительной документацией новых форматов, игнорирующей или признающей вторичными историкокультурные, художественно-композиционные и иные гуманитарноэкологические факторы, а потому ущербной и вредной и сегодня, и в долгосрочной перспективе для общественных и государственных интересов. Результаты - налицо (рис.33,34)

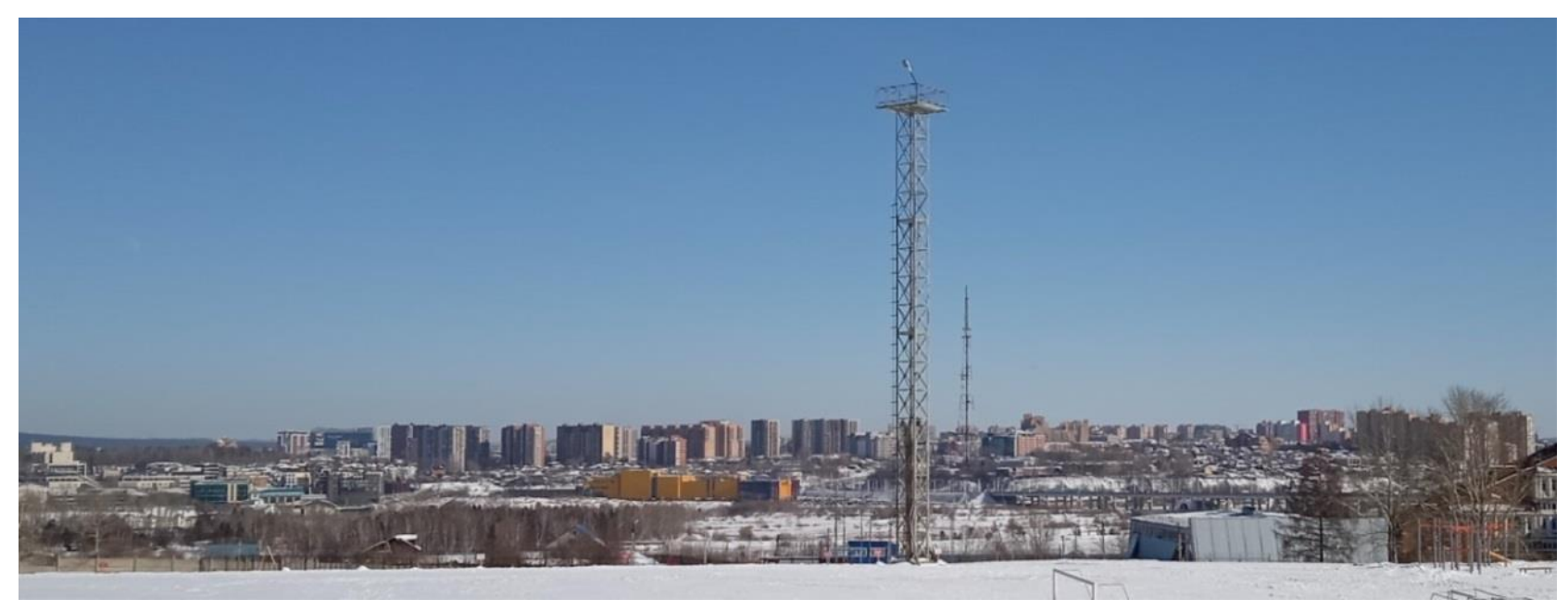




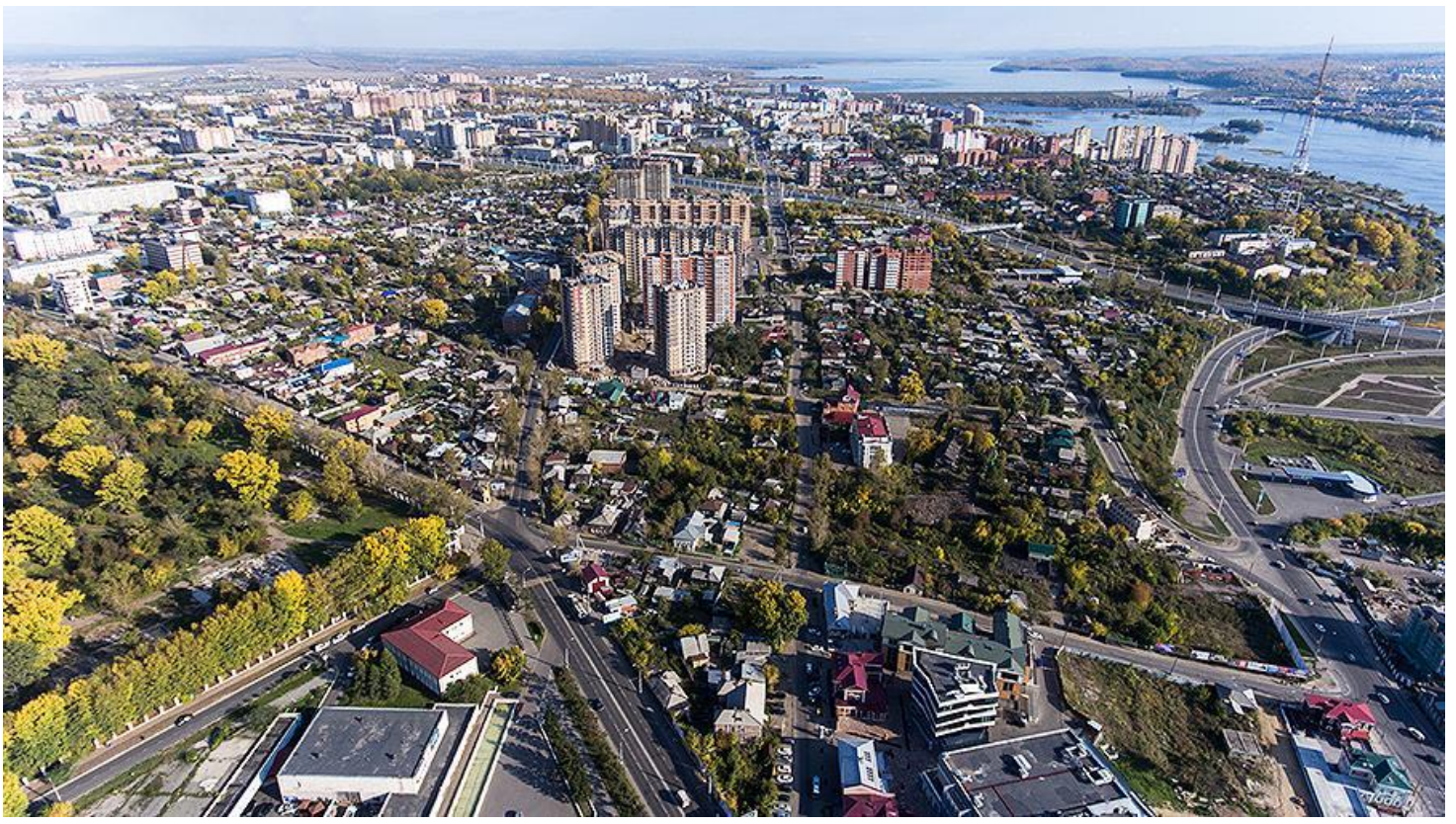

Рис. 33, 34. Недостатки новой жилой застройки города Иркутска, берущие начало в градостроительстве 60-70-х: нивелированный силуэт; отсутствие реакции застройки на природный рельеф, границы функционально-композиционных зон и речную акваторию; планировочный примитивизм; однообразие форм и цвета - при максимально возможной по местным условиям этажности (сейсмика 8 баллов)

Несмотря на то, что данные организационные аспекты градостроительства не являются основным предметом исследования в настоящей работе, их наличие лишь подтверждает главный тезис первой, вводной ее части/главы философского толка о нарастающем игнорировании существующей теперь, в начале уже нового XXI века, международной космополитической формацией (цивилизацией, эпохой) социальной и природно-культурной, в том числе эстетической составляющей интересов общества (а следовательно, и затрат на это) - в интересах извлечения прибыли крупными финансово-технократическими структурами, в свою очередь не отягощенными заботой о культурном развитии стран и просвещении местного населения и, как следствие, об отсутствии у данной формации сколько-нибудь отдаленных исторических перспектив. Отсюда и сегодняшняя планетарная политическая, экономическая и эпидемиологическая нестабильность. 


\section{Список литературы}

1. http://www.odinblago.ru/stepun_osvald Степун Ф.А. Освальд Шпенглер и Закат Европы.

2. http://kartaslov.ru/книги/Освальд_ШпенглерЗакат_Европы_Том_1/1\#c ontent Дубнов А. Общедоступное введение

3. Комментарий к Градостроительному кодексу РФ (под ред. С.А. Боголюбова) - ООО "Новая правовая культура", 2005 г.

4. http://www.hrono.ru/libris/lib_h/hrush07.php Никита Хрущев. Время. Люди. Власть. Воспоминания.

5. В. Глазычев «О градостроительном такте, профессиональной культуре и творческой свободе». Архитектура (приложение к «Строительной газете»), №14(446), 1979г.

6. Закон РФ от 14 июля 1992 года N 3295-I «Об основах градостроительства в Российской Федерации»

7. Постановление ЦК КПСС и Совета Министров СССР «Об устранении излишеств в проектировании и строительстве». Газета «Правда», №314 (13612) от 10.11.1955г.

8. Л.И. Кириллова «Вопросы композиции в русской архитектуре XVIХIX вв.». М.,1953

9. В.К. Олтаржевский «Строит-во высотных зданий в Москве». М.,1953

10. Ю.А. Егоров «Ансамбль в градостроительстве СССР». М.,1961

11. Проблема ансамбля в советской архитектуре. Под ред. К. Трапезникова. М.,1952

12. И. Араухо «Архитектурная композиция». М.,1982

13. Ю.С. Ушаков «Ансамбль в народном зодчестве русского Севера». M.,1982

14. https://myguidebook.ru/b/book/1970543998/8 Н. Кружков «Высотки сталинской Москвы. Наследие эпохи»

15. https://thehammerandthesickle.wordpress.com/author/koloto1/ Kafayat. Under the hammer and the sickle. Moscow's Unrealised Plan.

16. https://realty.rbc.ru/news/58f0556e9a794783d29a427e

Эксперты оценили объем хрущевок под возможный снос по всей стране. 